\title{
Exploring the Impact of the Counseling Service on Student- Teachers' Academic Performance: The Case of E.P. College of Education, Bimbilla
}

\author{
Ampong Emmanuel \\ Med. E. P. College of Education, Bimbila. Ghana W/A
}

\begin{abstract}
The study sought to explore the impact of counseling service on students' academic performance in E.P College of Education, Bimbilla. The objectives of the study were: one, to examine the impact of the counselling service on student-teachers' academic performance; two, to find out what motivates studentteachers to patronize the counseling service; and lastly, to find out the perception student-teachers have about the role of the counseling service in E.P. College of Education, Bimbilla. The study employed the qualitative approach with case study in focus. Two hundred and fifty (250) student-teachers, four (4) tutorcounselors and a vice principal were selected using the stratified sampling technique. The respondents were made to fill questionnaires and also interviewed. After successful data collection, the data was analyzed using SPSS version 17. The data was also analyzed using descriptive statistics such as frequency distributions and percentages. Qualitative descriptions were also used in the presentation of data. The study found out that counselling service equips student-teachers with good study and time management skills to improve their academic performance. The study concluded that counseling service could help student-teachers build positive self-image which could lead to better academic performance. One of the implications of the findings is that if student-teachers seek counseling, they would be assisted to develop good study skills.
\end{abstract}

Keywords: NDEA - National Defence Education, ASCA-American School Counselling Association, SCAGES - Standing Conference of the Association for Guidance in Education Settings, ACA-American Counseling Association, CRDU-Curriculum Research Development, Unit,. NCLBA-No Child Left Behind Act SAT-Scholastic Attitude Test, STPRGCRS-School Teachers' Perception of Guidance Counsellors' Rating Scale, SPSS — Statistical Packages for Social Sciences, FCAT_-Florida Comprehensive Assessment Test, AACD-American Association for Counseling and Development, ANOVA-Analysis of Variance, HIV-Human Immunodeficiency Virus. AIDS - Acquired Immune Deficiency Syndrome, UNESCO_United Nations Educational Scientific Cultural Organization

\section{Background to the Study}

It is an established fact that the world over has come to accept the need for the services of Guidance and Counseling in all spheres of life of every man on earth. Every traditional or modern society has some activities like initiations, training of the individual for a specific assignment in the society, the giving of advice on the essentials of life like marriage, the reverence given to an object of worship, the need to understand one's self (a person's strengths, ,aptitudes, attitudes ,likes and dislikes) and his or her human and physical environment(the ability to utilize the material resources in the environment for one's benefit and that of the society and to relate well with other people) to the less knowledgeable individual in the society are but a few of the guidance and counseling services rendered by people like counselors, parents, teachers, religious leaders, political leaders, traditional leaders and the like.

Historically, according to Bedu-Addo (2014), the earliest hint of guidance can be traced to the Greeks who trained their citizens to be useful to themselves and to their community. In ancient Egypt around $250 \mathrm{BC}$, it is believed that the earliest forms of guidance occurred when would- be pharaohs were schooled in the rudiments of governance. This included helping them understand their strengths, weaknesses and potentials as rulers, in addition to improving their weaknesses. It is also evidenced that some of the techniques and 
skills of modern-day guidance counselors were practiced by Catholic priest in the Middle Ages as can be seen by the dedication to the concept of confidentiality within the confessional process in the Catholic Church. Formal guidance programmes using specialized textbook and techniques as we have it today did not start until the turn of the twentieth century mainly in the USA. It is common knowledge that one of the reasons why the guidance services were introduced in the British educational system was the economic situation in the Isles after World War II. In addition, the multifaceted nature of the current day school counselor role has evolved since the onset of the $20^{\text {th }}$ century. At the beginning of the $20^{\text {th }}$ century, the United States was still immersed in the industrial revolution. Teachers were being appointed with the expectation that they would take on an additional role as a vocational counselor. The primary intent was to focus on career transition from high school to the work force. Although teachers were expected to now be counselors, they did not get paid more nor did they have a break during their day (Gyspers \& Henderson, 2001; Reiner, Colbert \& Perusse, 2009). As the $20^{\text {th }}$ century continued to unfold, economic, social and political events, along with education reform movements, shaped the nature and structure of school guidance and counseling programs. The vocation component remained, but by the 1950's, there was a personal/social focus, which emphasized a clinical perspective, with counseling dominating the role (Gyspers \& Henderson, 2001). The school counseling profession advanced even further when the National Defence Education Act (NDEA) was passed in part, as a reaction to the United States losing the space race to the Soviet Union. When the USSR launched Sputnik, the US recognized that as a nation, Americans were falling behind in math and sciences, thus potentially impacting the US's standing as a Super Power. The NDEA provided funding for more testing to be done in schools and training institutes for school counselors. Testing would allow for the continuous monitoring of knowledge, skills and performance of the nation's youth and children, particularly in math and sciences (Bauman, Siegel, Falco, Szymanski, Davis, Seabolt, 2003; Myrick, 2003). From 1951 to 1965, the number of school counselors jumped from 6,780 to more than 30,000. The NDEA added academic development to the role of school counselors. Each of these aforementioned events shaped the role of the school counselor into a complex, diverse, often misunderstood role, with an emphasis on the academic, career and personal/social developmental domains (Bauman, et al. 2003; Gyspers \& Henderson, 2001; Myrick, 2003).

The first hint of guidance in Ghana was in 1955 when a Youth Employment Service was established with a two-fold function. It's first function was to give vocational guidance to the youth, with the second being helping the youth find jobs(Bedu-Addo,1989). The discipline took center stage in the 1960s with the establishment of the Curriculum Research Development Unit(CRDU) to cater for programmes in school welfare services, education for the handicapped. This development called for the introduction and lunching of cumulative record cards in 1971 in Ghanaian schools in some selected districts (Atise,2013). According to Barki and Mukhopadhyay (1986), counselling is a process of enabling the individual to know himself and his present and possible future situations in order that he may make substantial contributions to the society and to solve his own problems through a face to face personal relationship with the counselor. They went further to say that counseling is a learning oriented process carried on in a social environment in which the professionally competent counselor attempts to assist the counselee using appropriate procedures to become a happy and productive member of the society by formulating realistic and purposeful goals for total personal growth. Counselling is not just giving information, or giving, suggestions and recommendations, even when requested for. Counselling is, therefore, aimed at bringing about desired changes in the individual for self-realization and providing assistance to solve problems through an intimate personal relationship. The objectives of counseling are to enable students to achieve positive mental health, resolve their problems, improve personal effectiveness and maximize individual freedom to choose and act within the conditions imposed by the environment. The role of the school counselor has evolved over the past one hundred years beginning with a concentration on career exploration, moving into personal/social counseling and then academic achievement. In the year 2011, school counselors continued to focus on the academic, personal/social and career developmental domains (Reiner, Colbert and Perusse, 2009). Marchetta (2011) opined that the role of the school counselor has been questioned for quite some time, and a few studies on the effectiveness of school counselors, or models that have been implemented to show the accountability of school counselors. The American School Counselor Association (ASCA) developed a program that was intended to assist school counselors in planning and delivering their services, while also creating opportunities for school counselors to demonstrate their effectiveness and program accountability. A 
successful school counseling program requires teacher involvement and support. Teacher support is often the result of teachers understanding and valuing the role of the school counselor. Corey (1986) stated that a counselor's role does not have a specific definition, therefore sometimes causing conflict of how others view their role. Thus, stakeholders such as teachers, may have unmet expectations of school counselors (ASCA, 2005; Clark \& Ametea, 2004; Reiner, Colbert \& Perusse, 2009).

Bimbilla is a district capital of the Nanumba-North district in the northern region of Ghana. It is a predominately Muslim community with farming as the major occupational activity of the indigenes. The population of the people in Bimbilla is about two thousand. There are so many educational institutions spanning from the basic level to the tertiary level. E.P. College of Education is the only tertiary institution in Bimbilla township with the mandate of training teachers to teach in the basic schools in Ghana. The college's student population stands at 1706 with a staff of about 70 of which 45 are teaching staff. The current situation about the academic achievement of students is fairly good and there is more room for improvement. History has it that the college began as a singleton institution with only males as students in 1962 and the level of discipline and achievements in sporting, cultural and academic activities were very high. However, when the college was made a mixed school some years after its establishment, the achievements of the students in academics, sports and cultural activities started to suffer retrogressing. One of the reasons attributed to this phenomenon was the fact that both the male and female students were not able to handle their social life on campus very well. Some engaged themselves in amorous relationship to the neglect of their books and their involvement in extracurricular activities such as sports and cultural activities. Currently, the college is putting measures in place to bring back the past glory of the college. Measures such as allocating a number of students to tutors who have been made academic counselors with the mandate to guide and counsel students on academics, personal-social and vocational concerns, awarding students who put up disciplined behaviors and achieve academic, sporting and cultural successes, seminars being organized for students every fortnight to discuss academic and non-academic issues, to mention but a few. The above interventional measures have started yielding some results and if the college wants to see high yielding results there would be the need for her to intensify her efforts. The current study will be exploring on how the counseling service impacts students' academic achievement.

\section{Statement of the Problem}

It is an undeniable fact that the major stakeholders in education the world over are putting measures in place to make the student a person who will be able to undertake his/her academic activities with ease and be able to realize his/her academic goals. Here in Ghana, the Ministry of Education, Youth and Sports as well as the Ghana Education Service has made guidance and counseling an integral part of teacher education programme to improve the academic and career needs of students(Ziggah,2010). The researcher has come to realize that there seems to be much publications on the impact of guidance and counseling on the academic performance of pupils/students at the basic and secondary levels and not at the tertiary level of education. Due to this state of affairs or vacuum, the current study will be conducted at a tertiary academic institution like E.P. College of Education, Bimbilla, in order to bring to the fore how the counseling service is positively influencing students' academic performance or otherwise. There is a seemingly negative perception among the academic members of the college community of the role counseling plays as far as the improvement of academic performance of student-teachers is concerned. There is a semblance of counseling services being rendered to student-teachers by the guidance and counseling coordinator and some tutorcounselors in the college. Truly speaking, the counseling service which is an integral part of the guidance services is considered to have the potency to help all categories of learners with their academic challenges and make them chopped up academic successes. Issues ranging from intellectual, emotional, social, educational to financial that positively and negatively affect the learning outcomes of students can rightly be dealt with in counseling.

It is, however, sad to say that the college's actions and inactions have made the counseling work unattractive to the college's counselors. The logistical and infrastructural support needed to be given the counseling unit is not forthcoming making the college's counselors very demoralized. More to the point, the manner in which student-teachers in E.P. College of Education, Bimbilla, perceive counseling may serve as a barrier to the counseling process. This perception may be derived from their prior experiences in or out of counseling and nature of their concerns. If a student-teacher has had poor prior counseling, his/her attitude towards 
seeking help will most likely tend to be negative. Student-teachers who have had good experience in counseling view the process positively. It is likely that they will think of counseling when they face inordinate personal difficulty in the school(Johnson,1970). Most student-teachers at E.P. College of Education, Bimbilla, have already formed social attitudes that are quite distinct and likely to remain fixed during their entire life. Nevertheless, changes in the cognitive component often results into changes in the affective and behavioral components(Gitonga,1999). However, according to Mbabu, (2005),"changes will disappear unless the environment is supportive of the behavior change that accompanies the attitude change. And individuals are likely to back peddle to their earlier attitude unless there is an environmental change that sustains the new attitude. In this case, positive attitudes towards counseling need to be reinforced while negative ones need to be discouraged". Students seek out different counselors depending on whether their concerns are of academic or personal in nature (Tinsley and Brown,1982). Some may refuse to open up and others are afraid of being seen with a counselor (Gitonga,1999). Perceived confidentiality could also influence the student help-seeking attitude. Students may prefer to seek help from either friends or relatives and only turn to professional counselors when helpers are unavailable or ineffective (Parham and Tinsley,1980). Thus, students are likely to seek assistance from a peer counselor than from a clinical psychologist for personal problems (Parham and Tinsley,1980). Another factor on preference for counselors focuses on the way clients perceive the expertise of the counselor. The information available to them about the counselor's status and experience (Brooks, 1974). In addition, Banikiotes, (1981) asserted that the counselor's gender has a great impact on clients because male clients have the greatest satisfaction with female counselors and have a high regard for them. Indeed, women express more comfort and are likely to disclose to female counselors than male counselors. It is significant to say that E.P. College of Education, Bimbilla, is a mixed school but unfortunately many of the college counselors are males since the ratio of the male tutors to the female tutors stands at $42: 4$. The afore-mentioned situations or conditions have made the counseling unit of the college not as vibrant as it is expected. Upon all these challenges facing the counselling department of the college, the college counselors are doing their possible best in helping the student-teachers out with their academic challenges making majority of the student-teachers able to chop good academic success at the end of every semester. But, honestly speaking, it is a fact that counseling activities which is on the low side in the college contributes about ten percent as compared to the ninety percent quantum of contribution made through dedicated teaching by tutors and the adequate support given to teaching activities by the college's management, to those academic successes of student-teachers of E.P. College of Education, Bimbilla. On the contrary, statistics taken from institutions like St. John Bosco's College of Education, Navrongo, and Tamale Girls Senior High School, have indicated yearly improvement in students' academic performance due to the yeoman's job the counselors do in those schools.

\section{Purpose of the Study}

The purpose of the study is to find out the impact of the counseling service on student-teachers' academic performance in E.P. College of Education, Bimbilla in the Nanumba North district. This research is a case study located in an interpretive-qualitative framework (Kusi, 2012). The purpose of the study was realized through, one, the collection of data from student- respondents using questionnaires and interview guides in their lecture rooms and a chosen place suitable for the conduct of the interviews respectively and, two, specially designed questionnaires and interviews guides were used to gather information from the vice principal, and the college's counselors. The researcher also collected transcripts of students who happened to be respondents of the study from the college's assessment officer. The collected data was organized and analyzed using descriptive and inferential statistical tools. Based on the analyzed data, the researcher then drew his conclusion concerning the research topic or problem or the purpose of the study.

\section{Main Objective}

The main objective of this study is to find out or explore the impact of the counseling service on studentteachers' academic performance in E.P. College of Education, Bimbilla, in the Nanumba North district.

\section{Objectives of the Study}

1. To find out the perception student-teachers have about the role of the counseling service in E.P. College of Education, Bimbilla.

2. To examine the impact of the counseling service on student-teachers' academic performance in E.P. College of Education, Bimbilla. 
3. To find out what motivates student- teachers to patronize the counseling service in E.P. College of Education, Bimbilla.

\section{Research Questions}

1. What are the student-teachers' perceptions of the roles of counseling service in E.P. College of Education, Bimbilla?

2. What is the impact of counseling services on the student- teachers' academic performance in E.P. College of Education, Bimbilla?

3. What motivates student- teachers to patronize the counseling service in E.P. College of Education, Bimbilla?

\section{Significance of the Study}

The study will improve upon the existing practices in the field of counseling by putting forward the bare facts to conscientize all stakeholders in the field of education about the role(s) they should play in order to help the student take informed decisions on his/her academic, career and personal-social concerns which in the long run will ensure the personal growth and development of the student and that of the society. For instance, management in every tertiary academic institution, especially, E.P. College of Education, Bimbilla, will now understand the need to provide funds and logistics to the guidance and counseling units of their schools in order to make the work of their schools' guidance and counseling units very efficient and effective,the teacher-counselors will use this results of this study to assess the impact that the counseling service can have on students' academic performance in their own schools, and the Ministry of Education and sports, the Ghana Education Service and the National Council for Tertiary Education will find the recommendations made by this study very useful in the formulation of educational policies that will better the academic lots of students especially the tertiary ones.

\section{Delimitation}

The study was at E.P. College of Education, Bimbilla, and not in all the schools in the Nanumba-North district of the northern region. Again, the study is delimited to the academic life of students and not to their vocational and personal-social lives. Lastly, the study's sample will be first and second year students and not third year students as participants or respondents.

\section{Limitation}

The study was limited by the use of the researcher's own data gathering instruments which are yet to be validated and as a result of this will cause the inapplicability of his findings to other situations.

\section{The perception on the role of counseling services in schools}

Awinsong, Omar, and Gidiglo (2015) conducted a study on the topic: Students' perception of the role of counselors in the choice of a career: a study of the Mfantseman municipality in the central region of Ghana. The study aimed at finding out the available counseling services in schools, the frequency of access to counseling in schools, and the perception students hold about the role of counselors in the choice of careers. The descriptive research design was used in the study. Student respondents numbered 349 while 2 counselors were involved in the study. Questionnaires and an interview guides were used to gather the necessary data for the study. The study revealed that counseling services that are available in schools include educational, vocational, and personal-social counseling. Secondly, the study found that students had access to counseling but their frequency of access was inhibited by counselor characteristics and other factors. Lastly, the study uncovered that students thought counselors to be central to the process of making career choices. The government, Ghana Education Service, and school authorities should give much heed to counseling especially career guidance by making resources available to counselors to work. Career guidance programmes should be routinized in schools for greater benefits to students. Counselors should also endeavour to seek opportunities for skill upgrade and higher training so that they can become more relevant to the needs of students.

Willy's research has indeed added a great amount of information to existing literature on counseling in higher educational institutions. In fact, the research design and instruments used for the study are very appropriate. The findings and recommendations for the study are in order and if looked at seriously by key stakeholders that concern themselves with higher education, things in the general society will become better 
for all. Nevertheless, the study's sample size is on the low side and may not allow for generalization of the findings from the accessible population unto the target population. In a study conducted by Eremie, (2015) on the topic: Teachers' perception of the roles of guidance counselors in secondary schools in Rivers State, Nigeria, simple random sampling technique was adopted to select three hundred and seventy (370) male and female secondary school teachers from a population of five thousand three hundred (5300) school teachers. The "School Teachers' Perception of Guidance Counselors' Rating Scale" (STPRGCRS) was administered to the respondents to collect necessary data. The t-test statistics was used to test three null hypotheses at 0.05 significance level. The findings revealed that there were no significant differences in teachers' perception of the role of guidance counselors in secondary school in Rivers State. Therefore, the three null hypotheses were accepted. Based on the above findings six (6) recommendations were made: (1) The government of Rivers State should endeavour to establish counseling units in each secondary school and should be functional to meet the needs of students. (2) Qualified counselors from accredited colleges and universities, with minimum qualification of bachelor in Guidance and counseling or psychology should be employed (3) Counselors should focus on counseling students as their primary functions. (4) Counsellors should hold staffing with parents, students and teachers as time will permit in each school session. (5) Counselors should strictly observe confidentiality as code of ethics. (6) Counselors should be able to refer students with major emotional problems to the appropriate helping professionals.

Ng'eno and Magut (2014) research has unveiled some needful information about vocational guidance and counseling. The study has also made a very good recommendation that needs to be looked at carefully and used by well-meaning individuals in the school's counseling fraternity. The study's sample size, data collection tools and statistical tools/techniques used were very appropriate. The current study will seek to explore the impact of the counseling service on students' academic performance in a higher academic institution such as the teacher training college to augment the seemingly small research works undertaken there. In another study on the topic: Student perception on current school counseling service in Sri Lanka (with reference to Anuradhapura zone), Chathurika, (2004) main focus was to identify the perception of students on school based counseling service in Sri Lanka. Schools and students in present classrooms are facing tremendous range of challenges due to significant changes of social-economic and cultural background and according to their development stages. To overcome these problems through schools and to enhance the personality development of students, school counseling has been introduced in Sri Lankan school system since 1960's. To enhance the current school counseling service in a productive way, perception of students, teachers and principals are more important as key stakeholders. Main objectives of this research were to identify students' perception on school counselling service, find out problems faced by students when receiving this service and what kind of service student prefer to have from school counselling service. Methodologically, the researcher worked with four schools in the district of Anuradhapura to gather raw data. 100 students were taken as the sample. A survey design was employed as the major research approach. Semi structured questionnaire and interview schedule was engaged to collect data as instruments. Majority of the students (73\%) have recognized counseling service as a method of giving advices by senior teacher/teachers appointed as counselors. As a main problem $65 \%$ do not have much confidence about the school counselor especially with individual counseling. For that reason, 52\% are not satisfy about the current counseling services in their schools and about the place that is used as counseling room. Most of the students prefer to have professional guidance, educational counseling and individual counseling for their personal problems with confidential counsellor. Therefore, this research recommended enhancing the awareness on school counseling among stakeholders to overcome these misconceptions. Moreover, it can be suggested to provide a better training for school counselors and to establish a good monitoring system and also sufficient facilities should be provided to the counseling service in school level.

Beesley (2004), conducted a study on teacher perception on the role of the school counselor. The study was conducted to see how satisfied teachers are with the overall role of a school counselor. Sixty-seven percent of teachers reported to be somewhat extremely satisfied with the counseling services provided in their school and 33\% reported that they were somewhat extremely dissatisfied with the services a school counselor provided. Elementary school teachers reported significantly greater satisfaction with school counseling services than middle /junior high or high school teachers. Teachers were asked to rate specific areas of service provided by their school counsellor and the strongest domain was classroom guidance, 
followed by individual/group counseling, consultation and coordination of special education services. The top four domains for recommended improvements were career counseling, academic planning/college preparation, community referrals and public relations. Overall, teachers were satisfied with the services school counselors provide but still believed that there were areas of improvement.

Beesley's study has significantly added much to existing knowledge in the field of counseling. It is worthy to say that this comparative study has brought to the fore which categories of teachers are very much aware of the role of counselors in schools. Again, the study did not fail to point out the fact that teachers were satisfied with the services rendered by school counselors but still believed that there were areas of improvement. In addition, the study has made school counselors aware of the domains or areas in their core mandate they need to hammer on in order to be seen to be relevant to all stakeholders, especially, the school pupils/students. The gap in Beesley's study is the fact that the study was conducted with primary and middle/high school teachers and not college or university teachers. The current study will seek to fill this gap by looking at the perception of college teachers on the role of college counsellors. In a study conducted by Aluede and Imonikhe (2002), students' expectations of school counselors are to assist in solving academic problems by developing study skills. Students view the school counselor's role as someone who has knowledge about school curriculum and can provide information about educational and career opportunities. Students also confide in their school counselors in regard to personal/social problems. It was found in this study that teachers believe strongly that the counseling department makes a positive contribution to the school's instructional program. Teachers also believed that counselors enhance instructional programs, and act as change agents in the school with regards to students' personal/social development, as well as academic development. Teachers also believed that school counselors designed appropriate interventions for students with special needs. According to the reviewed studies on stakeholders' perceptions of the school counselor's role, respondents were generally satisfied with the role of the school counselor. Another common finding was that teachers felt strongly that school counselors were not responsible for administrative duties, and when they have to carry out certain tasks, such as conducting psychological examinations, it took counselors away from their professional role.

\section{Impact of the Counseling service on Students' Academic Performance}

Abdulai and Inkoom (2016), conducted a study on the topic: "Guidance and Counselling in Early Childhood Teacher Training". Their study examined the place of guidance and counseling in early childhood teacher training. A 20-item questionnaire was administered to 486 students drawn from University of Education, Winneba (UEW) and University for Development Studies (UDS); both public universities engaged in teacher education. A descriptive survey was adopted for the study. The main instrument used for data collection was a questionnaire for Early Childhood Education students. The data gathered was coded and analyzed with the aid of computer software, Statistical Package for Service Solution (SPSS) version 17. The statistical tools used in the analysis consisted of both descriptive and inferential statistics. The open-ended data was also categorized and recorded according to themes for emergent patterns. It was evident from the research data that teacher trainees are aware of the availability of guidance and counseling services in their respective schools, which is mostly through the school counselor. Furthermore, this study presented viewpoints in relation to the needs of the students, how they are addressed, and how well these services are available. The study had added to existing knowledge on student perception about the place of guidance and counseling services between UEW and UDS. The paper drew on the findings and recommended that sourcing of guidance and counseling services should be mandatory on the part of students and that such services should not be limited to academic issues but should also address personal and social needs of recipients.

Abdulai and Inkoom (2016) research has produced another significant fact about the place of guidance and counseling in a successful academic life of students in tertiary institutions. The sample size for the research which is 486 is quite good in the sense that it has made it possible for the results to be generalized to the target population. It is worthy to say that the recommendation made by the researchers is very good. School counselors need to go by the recommendation in order to help produce students who are holistically well trained to solve their own problems and that of the society. The comparative study between the two institutions (UEW and UDS) has brought to light that similar situations (attitudes of students towards guidance and counseling and the impact of guidance and counseling on students' academic performance) 
exist in the two institutions. This can help government and other educational stakeholders to save money in organizing separate research in the two institutions. On the negative side, the researchers failed to use interview as a data collection tool. Interviews could have help the researchers to gain deeper understanding of the issue under study. Secondly, the researchers should have picked a larger sample size to help make generalization of the research findings very convenient.

Mckenzie et al. (2015) research on the effectiveness of University counselling for students with academic issues has added to existing knowledge in counseling. The research finding has brought to the fore some interesting revelation that "counseling was, however, shown to result in reliable and clinically significant change in a high percentage of those experiencing these additional difficulties". Counselling has been found to deal effectively with different challenges (personal-social, vocational and academic) of University students who patronize counseling services on campus. On the negative side, the sample size of 129 students is on the low side which cannot allow for the generalization of the research results. Again, the study delimited itself to the understudying of self-referred clients/students with academic difficulties. A suggestion should be made to future researchers to at least understudy both self-referred and referred clients in order to add more knowledge to existing ones for the benefit of formulating good educational policies by major stakeholders in education.

In support of the above research, Gatua, Sindabi, and Chepchieng (2015) conducted a study on the topic: "Impact of Guidance and Counselling services on students' behavior modification between selected public urban and rural secondary schools in rift valley province, Kenya". Their study sought to establish and compare the impact of guidance and counseling services on students' behavior modification in social and emotional adjustment in the selected public urban and rural secondary schools in Rift Valley Province, Kenya. The study adopted ex post-facto casual comparative research design. The research population was form 4 students in 24 secondary schools from municipality: Eldoret, Naivasha and Nakuru, and rural/district: Uasin Gishu, Kuresoi and Molo. Simple random, stratified and purposive sampling techniques were used to select 346 students, 48 school counselors and 48 school administrators as respondents. Quantitative data was collected by administering questionnaires to students and school guidance counselors while Qualitative data was collected through conducting an interview schedule to school administrators. Questionnaires were pilot tested before use and were found to have reliability coefficient of 0.8 . The study employed one-way analysis of variance (ANOVA) to test the hypothesis at 0.05 level of significance. The findings of the study indicated that guidance and counseling services in secondary schools had statistically significant impact on the level of social and emotional adjustments. Rural schools indicated high level of impact of guidance and counseling services where female students expressed higher level of behavior modification in social and emotional adjustment. It was concluded that guidance and counseling services in secondary schools helps in modifying students' behavior in social and emotional adjustments.

Gatua et al. (2015) research had good sample sizes in terms of figures and the use of relevant stakeholders that were much needed for the research. Of a truth, the use of questionnaires and interview schedules to collect data from respondents needs to be commended since each data collection tool is able to gather different types of data, that is, quantitative and qualitative data, respectively, bringing more understanding to the issue under investigation and revealing detailed information about the understudied phenomenon. Of course, the research could be done in a better way by the use of other relevant data collection tool such as observation to collect other important information that questionnaires and interview schedule are not able to capture.

Renuka, Devaki, Madhanka and Saikumar (2013) researched on the topic: "The effect of Counselling on the Academic Performance of College Students". They reported that the adjustment difficulties of college students have been an emerging issue. Many studies have proved that the adjustment difficulties like appetite disturbance, concentration problems and depression are most evident in freshmen. To help college students in resolving their adjustment issues, we made efforts in the form of establishing a counseling system to provide intervention to the students, so that their social and emotional problems did not interfere with their academic performances, for the current study. They chose to examine the relationship between the college counseling experience and the academic performance in a sample of freshmen. The aim of the study was to explore the relationship and the effect of counseling on the academic performance of college 
students. The objective of the study was in two folds namely: to find the relationship between the academic performance and counseling and to find the relationship between the number of sessions and the academic performance. On methodology of the study, fifty-four first MBBS college students of the SBMCH 20072008 batch, who underwent face to face individual intake interviews with college faculty members, were given questionnaires and the analysis was based on their response to the questions and their academic performance. The results of the study showed that there was an increase in the average marks by about $15 \%$ $25 \%$ among $43 \%$ of the students and by about $10 \%-15 \%$ of marks among $13 \%$ of the students. There was no marked improvement among $31 \%$ of them and there was no change in $4 \%$ of the students. The second part of the study showed that the number of sessions correlated positively with the academic performance. They concluded that the counseling services in colleges had been effective in easing out the students' personal difficulties. The constructive support which was received from individual counseling seemed to have a positive influence on the academic performance and the number of sessions correlated positively with the academic performance.

Renuka et al. (2013), research findings are pointing to the fact that effective counseling in colleges has a positive influence on students' academic life. In other words, when students are given much attention through the required counseling sessions on personal, social, career and academic concerns, they are able to make informed decisions and wise choices which in the long run turn their fortunes around. Renuka et al's research is delimited to freshmen (first year students). It will be good that future researchers who wish to conduct research with the same topic need to consider using more than one level, that is to say, using at least two separate cohorts of students (for example, level 100 and 200 students). Using at least two cohorts of students will ensure that research findings can be appropriately generalized. Odhiambo (2012) conducted a study on the topic: "Influence of guidance and counseling on academic performance of students in selected public secondary schools in Molo Sub County, Nakuru County, Kenya. The study sought to establish the influence of guidance and counseling on academic performance of students in schools in secondary schools in Molo Sub County. The study adopted an ex post facto design and targeted 1385 form four students and 24 teacher counselors in 24 public secondary schools in Molo Sub County. Random sampling was used to select a sample size of 86 students and 12 teacher counselors. Data was collected by the use of questionnaires. Descriptive statistics comprising means and standard deviations were used to analyze the data. Inferential statistics which included Pearson's correlation was used in data analysis. The hypotheses were tested at 0.01 level of significance. Data was analyzed with the aid of Statistical Package for Social Science (SPSS) version 21 for windows. The study concludes that guidance and counseling have a positive impact on the academic performance of students.

Kartika (2009), research has added some significant information to existing knowledge. Counselling services in schools continue to make meaningful impact on students' academic, career, and personal-social lives. It must be said here that the current study will try to fill the gap created by Kartika's research where he pointed out that most students still struggle in planning the operational steps to achieve he solution to their problems according to the requirement of it being specific, measurable, achievable, realistic, and having time limit by asking respondents how this come about if they experience a thing like that in their educational lives. Shaterloo \& Mohammadyari, (2011) researched on the topic: "Students' counseling and academic achievement". Education has a vital role in the development and abilities of students. With education expected of individuals (students) can develop to their full potential-potential qualified personal. Indicators of school success in carrying out his task can be seen from the achievement of high academic achievement and a variety of specialized skills possessed by learners and not the least of which involves issues related to academics. While students are required to continue to improve academic achievement, in the midst of busyness and density of both school assignments, academic assignments and extracurricular activities are followed by the students, so students need to follow the guidance and counseling services in schools to improve academic achievement. With such conditions it is necessary to investigate in depth whether the guidance and counseling itself may play a role in improving the academic achievement of students in school. School counselors address the academic and development needs of all students, not just those in need, by collaborating with students, parents, school staff and the community.

Shaterloo and Mohammadyari research has also added some significant information to existing research literature for counseling in schools. Indeed, the findings of the study point to the fact guidance and 
counseling services with other interventions can successfully assist students to actualize their academic dreams. A study conducted by Kituyi (2014), on the topic: "Guidance and counseling practice in relation to academic performance". The study was based on establishing the influence of guidance and counseling practice as applied in secondary school in relation to strategies towards academic excellence. The objectives were: to determine the effect of peer guidance and counseling in relation to academic performance, access its impact towards subject and career choices, determine the influence of the discipline of counseling towards performance and its effect on personal, social and moral challenges. The study adopted a descriptive research design. The target population comprised of Quality Assurance Officers, teachers and students in secondary schools in Bungoma County. The instrument used to collect data was a questionnaire. Data was analyzed using quantitative statistics and presented using tables and graphs with the aid of SPSS. The results show that, guidance and counseling as practiced does not meet the required standards of what is desired in academic performance. This has a direct bearing on human development that is related to what is effective practice regarding vision and mission of schooling: the self and self-conceptualization process for mastery of development tasks. These are agents of what constitutes comprehensive guidance and counseling practice. Further without access to counseling programmes, the self and self-actualization are jeopardized more so towards self-actualization, belonging, safety and expectation as a drive. Also, lack of visibility of counseling programmes poses a challenge, as this reflects lack of recognition. There is need to review guidance and counseling practices with the view of ensuring they meet the professional standards that lead to academic excellence thus performance. The recommendations are tailored towards guiding policy and mandating the practice. The study recommended that there should be a national policy put in place, to enable teacher training colleges and secondary schools have guidance and counseling included in their curriculum. In addition, the Ministry of Education should come up with alternative means of discipline in place of the corporal punishment that has been abolished and organize seminars to sensitize the teachers and students on a comprehensive practice of guidance and counseling. More than anything it should be comprehensive and should go beyond mere career guidance to disciplinary issues, personal-social-moral as well as support learning.

\section{The Patronage of the Counseling Service by Student-teachers}

Research conducted by Nam, Jung, Lee, Hee, (2010) on the topic: "A meta-analysis of gender differences in attitudes towards seeking professional psychological help". The objective of the study was to examine gender differences in attitudes towards professional psychological help-seeking behavior and how gender differences could be affected by other cultural factor such as race. The researchers selected studies that involved undergraduate and graduate students as samples, making the total number of participants in this meta-analysis 5,713. Statistical procedures were administered by the meta-analysis with interactive explanations program. The results indicated that gender itself was a significant predictor on attitudes toward seeking professional psychological help. In addition, individual's cultural background, example, western versus non-western ethnicity, moderated the gender differences on attitudes towards seeking professional psychological help.

Nam et al. (2010), research has added knowledge to existing facts in the field of psychology and counseling. It is a fact that female persons who are faced with emotional, psychological, financial, and marital problems are more likely to discuss their issues with someone with the aim of finding a lasting solution to the problems than male persons will do. More so, persons of highly educated backgrounds will have some appreciable understanding of what counseling is about and can therefore take advantage of it than persons whose educational background is very low. The researchers use of 5713 participants in their study is highly commendable. Using a number of participants like that will ensure generalizability of research findings. Nevertheless, the 5713 participants at some point in the conduct of the research may decline to be participants of the study for reasons best known to them, may die and therefore cease to be participants of the study and this situation may affect the reliability and validity of the research results. In support of the above research, Mackenzie, Gekoski, and Knox (2006) researched on the topic: "Age, gender, and the underutilization of mental health services: The influence of help-seeking attitudes". The objectives of this study were to explore age and gender differences in attitudes towards seeking professional psychological help, and to examine whether attitudes negatively influence intentions to seek help among older adults and men, whose mental health needs are underserved. To achieve these objectives 206 community-dwelling 
adults completed questionnaires measuring help-seeking attitudes, psychiatric symptomology, prior help seeking, and intentions to seek help. Older age and female gender were associated with more positive helpseeking attitudes in this sample, although age and gender interacted with marital status and education, and had varying influences on different attitude components. Age and gender also influenced intentions to seek professional psychological help.

Women exhibited more favourable intentions to seek help from mental health professionals than men, likely due to their positive attitudes concerning psychological openness. Older adults exhibited more favourable intentions to seek help from primary care physicians than younger adults, a finding that was not explained by age differences in attitudes. Results from this study suggest that negative attitudes related to psychological openness might contribute to men's underutilization of mental health services. Help-seeking attitudes do not appear to be a barrier to seeking professional help among older adults, although their intentions to visit primary care physicians might be. These findings suggest the need for education to improve men's help-seeking attitudes and to enhance older adults' willingness to seek specialty mental health services. Mackenzie et al. (2006), research findings has made academia and the general public aware of the fact that older adults are more likely to seek professional psychological help than younger adults. Also, female persons are more willing to seek help from a counselor than male persons. It is very refreshing to learn from their research that more education is needed to be given to older adults who are men to change their negative attitudes towards seeking for specialty mental health services. Besides these positives, the researchers fail to inform academia and the general public about measures than can be put in place to encourage younger adults to seek for professional psychological help. From a study conducted by Leong and Zachar (1999) on the topic: "Gender and opinions about mental illness as predictors of attitudes toward seeking professional psychological help" was to investigate the relationship between students' opinions about mental illness and their attitudes toward seeking professional help. By also using gender as a predictor of help-seeking attitudes, the researchers examined the effects of opinions about mental illness and the kind of attitudinal variables that should be more modifiable than gender identity. The results indicate that females had more positive attitudes toward seeking help than males, and that people's opinions about mental illness, especially more benevolent, less authoritarian, less socially restrictive and higher mental hygiene ideology perspectives, accounted for a significant percentage of positive help-seeking attitudes beyond the percentage accounted for by gender.

Leong and Zachar (1999), research has added a very significant knowledge to existing ones by discovering the fact that people's opinions about mental illness accounted for a significant percentage of positive helpseeking attitudes beyond the percentage accounted for by gender. Over the years, the issue had been that gender is the most predictive factor to indicate how female or male persons seek professional psychological help. Of a truth, one's view about mental illness, being stereotypical or non-stereotypical, can influence the patronage of professional psychological help by the individual. Patronizing public mental health services by a 'normal person' may cause other people to tag him or her as an insane person and this is very humiliating. A study on the topic: "Influences of gender and sex role orientation on help-seeking attitudes" by Johnson (1988), investigated into the influence of gender and sex role orientation on help-seeking attitudes. The researcher made use of two hundred and eighteen college students comprising 124 females and 94 males to complete the Bem Sex Role Inventory and the Attitude Toward Seeking Professional Psychological Help Scales. Results revealed that both gender and sex role orientation significantly influence help-seeking attitudes. Women were more tolerant of the stigma associated with seeking professional help, more willing to recognize personal need for help, and more open to sharing problems with others. Students classified as feminine were more confident in professionals' ability to help with personal problems and, along with androgynous students, were more willing to recognize a personal need for help.

A study conducted by Asamari, (2015), on the topic: "Counselling services in Colleges of Education in Northern Ghana". It was carried out in three (3) colleges of education in northern Ghana. The purpose of the study was to investigate the provision of guidance and counseling services and the perceived benefits of these services. The study adopted the descriptive survey design. Questionnaires and interviews were the tools used to gather data for the study. A multi-stage sampling technique was used to select a sample of four hundred (400) students from the three sampled colleges. Purposive sampling technique was also used to select three (3) counselors and three (3) principals for the study. Also, thirty (30) students were also 
conveniently selected for focus interview. The SPSS software package was used to analyze the data. The data was organized into frequency counts and converted into percentages which formed the basis for discussions. The interview data was recorded, transcribed, coded and built into relationships. Themes then were developed from the relationships for discussion. The study established that orientation, information, appraisal, counseling and placement services were the major guidance and counseling services provided at the colleges. Furthermore, the study indicated that inadequate funds, workload of counselor-teachers, lack of computers, internet and telephone facilities and inappropriate or wrong location of counsellors' offices were the major factors that inhibited the delivery of guidance and counseling services in the college system. Provision of adequate funds and reduction of workload or teaching load for counselors among others were the recommendations of the study. The current study will seek to add to the research work done by Asamari and others in order to make a case for effective and efficient Guidance and counseling services in northern Ghana in particular and Ghana as a whole.

\section{Types of Counseling Situations}

Pietrofesa et al .(1984) and Myrick (1987) cited in Bedu-Addo (2014), postulated that the types of counseling situations are crisis counseling, facilitative cousnselling, preventive counselling, and developmental counseling.

\section{Crisis counselling}

Brammer, (1973) defined crisis as a state of disorganization in which the helpee faces frustration of important life goals or profound disruption of his life cycle and methods of coping with stress. Thus, the crisis period of an individual who seeks counseling is such an extremely critical period that it can make or break the individual. Thus a counselor dealing with this kind of situation must be very delicate with such a client. Poal, (1990), discussing types of crisis opined that all of us at some time in our lives have witnessed or experienced crisis situations- loss of a loved one, drug induced crisis, inability to cope with life situations, a family crisis, an interpersonal crisis reaching the stage where it is immobilizing and prevents one from conscientiously controlling oneself, then it becomes the type of crisis for which a person seeks treatment. Belkin (1973), observes that crisis situation can be related to suicide attempt, unwarranted pregnancy, hospitalization, job relocation, imprisonment, or financial problems. But regardless of the nature of the crisis the counselor needs to accept the situation and maintain personal poise and self-assuredness. This type of confidence certainly reduces the anxiety and pains of the problem on the part of the client. Belkin (1973), offers suggestions for the counselors' behavior in such crisis situation in what he called "Do's and Don'ts in crisis intervention counseling.

Do's:

i. Remain calm and stable. Prepare yourself psychological for the turbulence of emotion which is soon to flow from the client.

ii. The client should be given opportunity to speak. Attempt to determine the type of crisis, it's precipitating force and it's severity. Interrupt only when it is for the client's benefit.

iii. When necessary, ask object-oriented questions. This, if well framed will have calming effects on the client. If it fails, the counselor should count himself/herself as asking egocentric questions.

iv. Deal with immediate situation rather than it's unconscious underlying causes that may be left for later. In the crisis period, Brockopp, (1973) point out, the person is open to change, the sooner we can work with him the more likely we are able to minimize the possible deterioration of personality and to develop an effective solution which will improve the personality functioning of the individual.

v. Have readily available local resources to assist the counselor.

\section{Don'ts:}

i. Don't try to cheer up the client and tell him that his problem is not as bad as they seem to reassure him unless he specifically requests these type of invention (which is by the way, the exception rather than the rule).

ii. Don't ask the suicidal client to abandon his plans. Always make such request a temporary delay.

iii. Don't try to solve the total personality adjustment difficulty. Some counselors try to minimize the crisis itself and attempting to get the client to speak on "fundamental thing". 


\section{Facilitative counseling}

This is a process of helping the client to clarify a concern through self-understanding and acceptance, to devise a plan of action to work on the concern, and finally to work on it in a self-responsible manner (Pietrofesa et al., 1984). This type of counseling situation is also designated remedial or adjustive counseling situation. According to Carkuff, (1983), in facilitative counseling, the counselor assists the client through the cyclical process of exploration, understanding and action. The concern areas of facilitative counseling include making and choosing academic options, planning and choosing a career, family growth and relationship, identifying individual strengths, interests, aptitudes, abilities and many other areas. Indeed, most day-to-day counseling activities and concerns in school settings especially are facilitative in nature.

\section{Preventive counseling}

Pietrofesa (1976), and White and Kelly (1976) support this particular counseling role. They noted that counselors must work with the youth to help them understand themselves in relation to sexual concerns so that they are better prepared to handle them in the future. Other areas of preventive counseling include increasing self-awareness as it relates to future career choices and career preparation, drug awareness, retirement preparation and improving communication skills (Carkuff \& Friel, 1974). Another important aspect of preventative counseling is the provision of up-to-date relevant information to a group of needy students or make referral to a relevant programme either on a group or one-to-one basis. According to Myrick (1987), all the things that society is trying to prevent young people from experiencing: sexual promiscuity, unwanted pregnancies, drug abuse, excessive absenteeism, poor study habits, juvenile delinquency, smoking, over eating, laziness, reckless driving and unemployment are all within the purview of preventive counseling.

\section{Developmental counseling}

This is an on-going process that occurs throughout an individual's entire life span. It focuses on helping clients to achieve positive self and personal growth at any stage of their lives (Bedu-Addo, 2014). Dinkmeyer (1966) described developmental counseling especially in elementary school as follows: "developmental counseling, which can be contrasted with adjusted or crisis counseling is not always problem-oriented in terms of assuming that the child has some difficult problem. Instead it emphasizes development of self-understanding, awareness of one's potentialities and methods of utilizing one's capacity". Developmental counseling truly focuses on helping the individual know, understand and accept himself. Havinghurst (1980) opined that developmental counseling helps the individual learn how to achieve healthy growth in society. Thus, counselors can through this process aid individual at all age levels and whole-heartedly support them in overcoming their developmental tasks. Van Hoose and Worth (1982) opined that counselors with an understanding of developmental psychology can effectively aid clients as they progress through various stages and transitions in their development. In addition, the focus of developmental counseling include among others, developing and maintaining positive self-concept, finding an appropriate lifestyle as it relates to use of working, leisure time learning decision making skills, clarifying ones values and interest, understanding and accepting changes, and developing life process from birth to death ( Pietrofesa, 1973). The meeting point of crisis and developmental counseling is that in dealing with grief over personal loss, can be considered crisis counseling in the sense that the grief may be over powering at first, but it fit into the developmental frame work as the client learns to cope and adjust with the bereavement. A professional who had been conducting developmental counseling is better prepared to work with the concerns that arise in preventive, facilitative and crisis situations.

\section{Academic/ Educational counseling}

The term educational counseling was first coined by Truman (1914) cited in Makinde, (1988), and he defined it as a "process of rendering services to pupils who need assistance in making decisions about important aspects of their education, such as the choice of courses and studies, decisions regarding interests and ability, and choices of college and high school." Atise (2013), academic counseling includes helping students to acquire skills, attitudes and knowledge that contribute to effective learning in school; employing strategies to achieve success in school; and understanding the relationship of academics to the world of work, and to life at home and in the community. Brown (1999), opined that school counselors are under 
pressure to assist in the effort to increase student achievement. They can respond to this challenge by working to improve the school climate, using direct interventions such as teaching study skills and involving students in achievement motivation groups, and by increasing the involvement of parents in the educational process. On improving the school climate, he discussed that High profile school violence incidence in Colorado, Arkansas, Kentucky, and Mississippi have found the nation's attention on alienated students. However, alienated students rarely go on violent shooting sprees. More often students who feel they have no place in schools disengage psychologically, and often physically, from those schools. The results is lowered achievement levels (Nelson, Covin, \& Smith, 1996) and higher dropout rates. Schools with positive school climates have teachers and others who are seen as warm and caring, have educational policies that foster educational and personal development, and recognize students' efforts and accomplishments (Purkey \& Schmidt, 1996). In-school suspension programs are policies that promote educational development. Out-ofschool suspension programs provide no benefits to students and discourage their achievement. Educators who know students' names, recognize their efforts, and provide academic support encourage educational and student development. Those who do not care, fail to listen, and refuse to recognize individual differences in achievement potential contribute to the alienation of students.

School counsellors can improve the climate of their schools by advocating for policies that promote rather than detract from the personal and educational development of students. They can do this by conducting inservice training of teachers and administrators to teach them basic communication skills, and methods of affirming students' importance and providing encouragement to them. One of the interesting bits of rhetoric that has emerged from the school reform movement is the need for smaller schools because large schools are viewed as too impersonal. It is argued that in small schools, teachers, administrators, and counselors will know every student personally and students will have increased opportunities to participate in school activities. Arguments for smaller schools are at least partially responsible for the development of charter schools, but these schools serve only a very small percentage of students. However, school counselors need not wait until schools become smaller to personalize the educational environment. They can become the students' anchor persons so that through the use of routine conferences, students feel that at least one person in the school knows and understands their unique concerns. Additionally, they can take the initiative to help students develop a sense of belonging by involving them in school clubs and activities. One middle school counselor identified all the students in his school that did not belong to a club for those students and helped them develop a service-oriented mission. One of their service activities was to direct traffic at all school functions, which gave students in the club high visibility in the school. School counselors can also help develop a positive school climate by sponsoring and conducting awards programs. Many schools have award programs in place, but unfortunately they are set up to honor those students who are number one in a given area. If award programs are to positively influence the environment of the school, they must impact a wide variety of students. Students who are working to improve their achievement, extend support and assistance to others who are striving to improve, exert energy to achieve even if the results are not exemplary, all need recognition. For example, awards can be given to the scholars of the week, the most improved students in math, science, language arts, etc., students who contribute the most to the achievement of others, the peer tutors of the week award, and so forth. Counselors can work with teachers and administrators to establish these awards and maintain a series of bulletin boards that have the Polaroid pictures of the various award winners posted. They can also name award winners in "Achievers Newletters", post their names on their schools' websites, issue bumper stickers to students that tout their achievements, and send notices to parents about their children's achievements. Regular school assemblies can also be held to honour award winners. Perhaps the spirit of what is being advocated here can be found in the work of a high school counselor. At the end of each grading period, she sent "almost made it letters" to students who narrowly missed the A-B honor roll, congratulating them to keep aspiring. On direct interventions, school counselors can improve the nature of the achievement climate in their schools. They can also draw from a vast array of interventions that will help students increase their academic achievement (Brown, 1999). One intervention that has been used for more than a quarter of a century is behavioral contracts. Unfortunately, this intervention has not been properly applied and has not had the results that many teachers and counselors expected. If behavioral contracts are to be effective they must have specific objectives, set attainable shortterm goals, be monitored regularly, allow for immediate, and be adjusted when they are not promoting the desired change. 


\section{Career/Vocational Counseling}

According to Watts and Fretwell, (2004), cited in Loan and Van (2015), career guidance and orientation services have been defined as services intended to assist individuals of any age and at any point throughout their lives, empowering them to make educational, training, and occupational choices and to manage their careers. They include three main elements: (1) career information, (2) career counseling, and (3) career education (Watts \& Fretwell, 2004, p.2). Career guidance in schools usually focuses on career information that provides information on courses, occupations and career paths. It also includes labor market information. The aim of career counseling in schools is to hold one-on-one or small group interviews focused on the distinctive career issues faced by individuals, such as career in education. Being part of the educational curriculum, attention is paid to help groups of individuals to develop their competence to manage their career development. The role of career guidance is not limited to education process but it also affects the national social and economic development. Sultana and Watts (2005), formal career guidance services are derived from economic and social development, playing a crucial role in helping to coordinate the education system and the labor market, in order to realize their goals successfully.

Generally, the aim of career guidance is to help students make decisions based on their interests, passion, and abilities, while taking into account current and future career opportunities. Students are encouraged to learn more about the world of employment across different industries, so that they may take right steps to obtain their objectives, goals and aspirations (Ministry of Education, Singapore, 2017). Another perspective indicated that career guidance can be referred to as services and activities intended to assist individuals of any age and at any point throughout their lives, to make educational, training and occupational choices and to manage their career (OECD, 2004). "Career guidance" denotes systematic programs that facilitate individual career development and career management (Herr \& Cramer, 1996). As discussed above, career guidance renders services and activities that are geared towards helping individuals of any age at any point throughout their lives to make their educational training and occupational choices in order to manage their career (OECD, 2004). As it is pointed out by Herr and Cramer (1996), career guidance offers systematic programs that facilitate individual career development and career management. Career guidance is much more than mere face to face interviews: SCAGES (Standing Conference of the Association for Guidance in Education Settings, UK, 1992) recognized eleven different activities of career guidance, such as informing students about the current and future opportunities of job market, advising, assessing, teaching, enabling, advocating, networking, giving feedback, managing and innovation or systems change.

\section{Personal-Social Counseling}

Atise (2013), discussed that goals guide the school counseling program to provide the foundation for personal and social growth as students' progress through school and into adulthood. Personal/social development contributes to academic and career success by helping students understand and respect themselves and others, acquire effective interpersonal skills, understand safety and survival skills and develop into contributing to the wellbeing of members of the society. Personal counselling deals with emotional distress and behavioural difficulties, which arise when individuals struggle to deal with developmental tasks. Any aspect of development can be turned into an adjustment problem, and it is inevitable that everyone encounters, at some time, exceptional difficulty in meeting an ordinary challenge. For example, insecurities about getting older, depressive feelings when bored with work, excessive guilt about a serious mistake, a lack of assertion and confidence, grief over the loss of a loved one, disillusionment and loneliness after parents' divorce.

\section{Individual Counselling}

It is a process whereby a counselor helps an individual to gain an understanding about himself/herself and forsters the development of skills to be used in dealing with difficulties associated with personal, academic and social life. The process works on the basis of trust and principle of confidentiality (Atise, 2013).

\section{Group Counselling}

Kottler and Brown (1996) cited in Ziggah (2010) conceptualized group counseling as a situation where a counselor helps clients to work towards individually designed goals, but with a common interest of becoming more intimate, trusting, accepting, empathic, and interpersonally effective. In summary, group counseling is the self-created supportive environment that creates a drive towards sanity and health so strong 
that group counselling enable members to develop their true potentials. It offers unique opportunity to deal with diversity in a safe environment. According to Kankam and Onivehu (2000), group counseling is both preventive and facilitative. The techniques and strategies are designed to help resolve inter-personal conflict, promote greater self-awareness and insight and help individual members work to eliminate their selfdefeating behavior. According to Shertzer and Stone (1980), the optimal number of individuals in group counseling is six but may vary from four to eight. In educational settings, Kankam and Onivehu (2000) stated that group counseling is of great significance due to the following: exploring what it means to be a person-"who am I really" ? "what do I want out of life"?, developing greater confidence in one's own perceptions, integrating one's feeling and thinking and becoming effective in social situations.

\section{Perceived Benefits of Guidance and Counseling services}

According to Asamari (2015), the benefits of guidance and counseling services are categorized into three broad areas namely educational/scholastic/academic benefits, career/vocational benefits and personal-social benefits. For the purpose of the current study, discussion will focus on only educational/academic benefits.

\section{Educational/ academic Benefits}

As far as the benefits of educational and academic guidance and counseling are concerned, Lapan, Gysber and Petroski (2003), Brigman and Campbell (2003), Schmidt (2003), Beale (2004) and Carey (2006) have argued in different studies that guidance and counseling services improved students' school attendance and their academic achievement. Similarly, Leviton (1997), established that guidance and counseling services assist students with concerns such as academic planning, study skills and teacher relationships. Zimbabwe Secretary's Circular N0. 2 of 2000 stated that guidance and counseling are for all students especially those who are under-achieving or at risk of dropping out of school. Racho, Aloka, Wambiya, and Raburu (2014) acknowledge that guidance and counseling services prepare and develop students' academic competences which result in good performance in schools. Brigman and Campbell (2003) conducted a study using a quasi-experimental design to evaluate the effects of counselor-led interventions on students' achievement and behavior. Using Mathematics and Reading scores from Florida Comprehensive Assessment Test (FCAT) as their dependent measure, students' achievements were evaluated. The scores of the students randomly selected from schools with equal racial and socio-economic make-ups in the treatment group were contrasted with the students in the control group that was matched for achievement levels. They found out that implementation of Students Success Skills Curriculum as a school counselor-led intervention programme did result in significant gains in students' achievement on the Florida Comprehensive Assessment Test (FCAT). In both reading (P-value less than .003) and Mathematics (P-value less than $.001)$, students in the treatment group had higher group mean scores than their counterparts in the control group. Akpa, (2013) investigated the provision of guidance services in colleges of education in the Volta Region of Ghana. A stratified random sampling techniques was used to select 155 teachers and 500 students. Questionnaires and interviews were used to collect data for the study. The study revealed that the benefits of guidance and counseling services for students were varied. They include improved study skills, efficient use of time, high academic achievement, reduced examination anxieties, and developed positive self-image. Similarly, Andoh-Robertson (2013) confirmed in a study that guidance and counseling services helped students improved academic achievement of senior high school students in Asikuma-Odoben-Brakwa District in the Central Region. It is established from the above analyses that guidance and counseling services enhance students' academic achievement, make students feel comfortable at school, improve school attendance and result in the improvement of academic performance of under-achievers (Asamari, 2015).

\section{Factors that hinder effective guidance and counseling in schools and colleges}

Below are some of the factors that hinder effective guidance and counseling in schools and colleges:

\section{Training of teacher/counselors in guidance and counselling:}

Okumbe (2001) as cited in Odhiambo (2015), defines training as the process of providing teachers and other employees with specific knowledge and skills in order to enable them perform specific tasks. Lack of professional training on the part of the counselor may have negative impact on students at the receiving end of such services since such counselors do not know the essential elements and core conditions of counseling, they cannot counsel effectively (Abdul, 2012). Students who are left to the mercy of such counselors will 
take actions to the detriment of the society. Such students cannot make good decisions; they may take actions that are not needed at a particular point in time.

\section{Facilities and resources used for guidance and counseling}

Odhiambo (2015) opined that the provision of facilities and resources in guidance and counseling departments in secondary schools is hindered by inadequate funding. According to Kafwa (2005), funding has been a major obstacle in many countries, he had that, without funding, teachers are paralyzed in their responsibility of providing guidance and counseling to students. Inadequate funding leads to lack of facilities and resources and this is the main hindrance to effective guidance and counseling as a result counselors are not motivated enough to carry out their assigned duties effectively. Abdul (2012) as cited in Odhiambo (2015) states that sometimes counselors are compelled under given circumstances to use their own money for purchase of items such as books, files, and pens which they need to carry out their duty. He added that there are also instances where counselors need money to go for more information that will help in finding solution to certain problems their efforts are usually foiled up if the school cannot afford to fund such trips. Most countries have no provisions for guidance and counseling programs, whatever funding available for implementation of guidance and counseling programmes is ad-hoc and grossly inadequate (UNESCO, 2007). In his study Kafwa (2005) as cited in Odhiambo (2015), found out that the following resources are not available in the schools studied in Kenya: motion film projector, audio cassettes, and video cassettes recorder, teachers should therefore be supplied with relevant materials for the success of the guidance and counseling services. Some of the challenges pointed out by Mutie and Ndambuki (1999) which affect provision of physical facilities and other resources in the guidance and counseling are that, reference books in guidance and counseling departments in secondary schools are very few, and some school head teachers consider guidance and counseling as a luxury, and not a priority. The counsellors' office should have furniture that include a desk and chair (Frank and Karyu, 2005) they add that clients seem to work better if their chair is reasonably padded but not overly stuffed. This is because clients seated in overstuffed chairs may feel almost too relaxed and may even get to the point at which they lose motivation to work on their problems, there is need to find out the influence of these facilities and resources on the effectiveness of guidance and counseling in Nyakach district secondary schools.

\section{Readiness of students to seek guidance and counseling services}

According to Rana (2000), as cited in Odhiambo (2015) most students seek counseling when a crisis point is reached. That is, when they cannot find a way of moving forward on their own and they realize that they are in need of help. Mutunga (2003) found that the level of voluntary counseling was very low due to lack of trust, fear of victimization and poor counseling atmosphere. He noted that students were yet to perceive guidance and counseling positively and embrace it appropriately. Wambui (2003) established that although students are faced with many personal problems, very few visit guidance and counseling center, the feelings they have are reflected by the behavior they display. Most students seek help from their peers than from the teacher/counselors (Ogoda, 2009). Counselling officers should be located in places where students are able to visit them at any time without feeling intimidated, it should allow for privacy so that the students can discuss any issue with ease (Wango, 2006). Lack of confidentiality may hinder students from seeking guidance and counseling. Confidentiality means that counselors will not disclose to others what a client has said in the counseling session without the permission of the client (Frank and Karyu, 2005). Religious differences between the counselee and the counselor also hinder students from seeking guidance and counseling services (Abdul, 2012).

\section{Measures/ Policies to Improve the Effective Delivery of Guidance and Counselling Services in Schools}

Mensah (2007) cited in Asamari (2015), established in a study that measures that could enhance the delivery of guidance and counseling in teacher training colleges in the Eastern region of Ghana included enhancing privacy for counselors, supply of files, cabinets, create awareness about the importance of guidance and counseling, organize regular talk shows, incorporate guidance and counseling into college time table. Similarly, Akpa (2013) as cited in Asamari (2015) revealed that provision of offices for counselors, provision of adequate funds and the use of role models and external resource persons for talk shows and seminars are measures that could improve the livery of guidance and counseling services in colleges of education in the Volta Region. Sackey (2007) as cited in Asamari (2015), recommended the reduction of teaching load of counselors, provision of office accommodation, and sponsorship packages for 
counselors to attend seminars and workshops to update their knowledge and skills in counseling to attend seminars and workshops to update their knowledge and skills in counseling as measure that would enhance the delivery of guidance and counseling services in secondary schools in Central Region. In another study, Larsey, (2013) as cited in Asamari (2015), concluded that measures that could improve the delivery of guidance and counseling services for senior high school students in the Kpando Municipality were the provision of equipment, detaching counselors from teaching to give time to perform their counseling role effectively and sponsorship of counselors to training, seminars and workshops to enhance counsellors' capacities. Mawusi (2013) as cited in Asamari (2015) also found out in a study that building the capacities of counselors through seminars and conferences would enhance counselors' abilities to provide expert guidance and counseling services to students in Junior High Schools in the Volta region of Ghana.

\section{The confidentiality of the counseling service}

A research conducted by Jenkins (2010) published an article titled "Having confidence in therapeutic work with young people: constraints and challenges to confidentiality" in the British Journal of Guidance and Counseling. In the abstract of his research report, he wrote that confidentiality presents particular challenges to practitioners working with young people, on account of the latter's vulnerability and emotional immaturity. Ethical codes place a key importance on confidentiality, from deontological and teleological perspectives. However, young clients may rely on a more pragmatic approach in deciding whether to disclose personal material to a counselor. Surveys indicate that young people place high value on confidentiality in school and healthcare advice settings. Practitioners may perceive constraints and challenges to providing high levels of confidentiality to young people, in the form of assumed duties to report child abuse, under-age sexual activity, and the need to obtain prior parental consent for counseling. These apparent constraints are clarified in the light of recent statute and case law, which in reality, provide robust support in law for counselors providing high levels of confidentiality to young people. Jenkins (2010), research findings has brought to light the need for counselor not to take advantage of the age of young people who are their clients and divulge information about their clients to third parties. It is the gospel truth that the hallmark in counseling is the fact that the counselee can have confidence in the counselor in order to open up to the client and having the assurance that his/her case or problem shall not be disclosed to any other person without his/her consent.

In support of the above research, Moyer and Sullivan (2008), conducted a research on the topic: "Student Risk-Taking Behaviours: When Do School Counselors Break Confidentiality?". They reported that a total of 204 middle and high school counselors from across the United States responded to a survey in which they were asked to determine whether they view specific adolescent risk-taking behaviours of varying intensity, frequency, and duration as warranting parental notification. Results suggest that counselors' perceptions that it is ethical to break confidentiality and report the risk-taking behaviors increased when the behaviors were more intense, more frequent, and of longer duration. Further, although there was less ambiguity regarding the perceived dangerousness of some behaviours (example, suicidal ideation), all behaviours showed some variance or disagreement among respondents with regard to their willingness to break confidentiality. Moyer and Sullivan (2008), research report has made important suggestions to counseling practitioners about behaviors of clients that need not to be protected with the principle of confidentiality in counseling. Behaviours such as suicidal tendencies, rape, murder, drug addiction and the like need to be made known to relevant stakeholders like parents, guardians, marriage partner, relevant security agencies and health institutions for a lasting solution to be found to the client's concern/problem. On the negative side, the number of respondents which is 204 middle and high school counselors across the United States is on the low side. This situation does not allow the results of the research to be generalized.

A study conducted by Harding, Gray and Neal (1993) researched on the topic: "Confidentiality limits with clients who have HIV: A review of ethical and legal guidelines and professional policies". They reported that the publication of the first counseling articles addressing confidentiality limits of clients who have HIV (Human Immunodeficiency Virus) and continue to be sexually active with an uninformed partner occurred four years ago. Since that time, dialogue about whether a helping professional may ethically and legally breach confidentiality has not resolved the dilemma but instead has created more questions and controversy for counselors. In this article, the authors highlighted the barrage of ethical issues regarding HIV and Acquired Immune Deficiency Syndrome (AIDS), review ethical and legal guidelines pertaining to HIV and 
AIDS and confidentiality, summarize HIV and AIDS confidentiality policies of the major helping professional organizations, articulate questions that contribute to the confidentiality dilemmas, and challenge the American Association for Counselling and Development (AACD), to develop specific guidelines for counselors.

Harding et al. (1993), research findings has brought to light the need for counselors to divulge information about a sensitive or personal problem like HIV/AIDS status of a client to his/her partner in order to deal with the spread of the disease and to help in the management of the disease where both partners have already contracted the disease. It is very worthy to say that a research such as Harding et al's should be carried out in a different setting such as tertiary institutions in order to help students who have concerns about their HIV/AIDS status and that of their partners to be released of the stress that go with HIV/AIDS issues which have a rippling effect on academic life. The current study may look at this HIV/AIDS concerns in E.P. College of Education, Bimbilla, but the researcher will not report on it. Annas (1976) researched on the topic: "Problems of Informed Consent and Confidentiality in Genetic Counseling". The premise of Annas's paper was that all persons who are given genetic counseling should be provided with complete and accurate information concerning the procedures used, the results obtained, the alternatives available, and the reasonably expected risks and problems associated with each such alternative. This premise is based primarily on the right of citizens to self-autonomy, and upon a definition of genetic counseling that has as its primary purpose the "explaining of predicted recurrence risks, with the relevant scientific basis, and describing available reproductive options to families with genetic problems". To further the patient's interest in both autonomy and privacy, no information obtained in genetic screening or counseling should be disclosed to any third party without the patient's informed consent. The above research by Annas, (1976), has brought to the fore another significant discovery about confidentiality in counseling. Of a truth, issues from genetic counseling needs to be handled with high confidentiality by counselors just because any disclosure of information without the consent of the client can cause stigmatization of the client by the people in the society, depression for the client, dissolution of proposed marriages and the like. More to the point, counselors in schools should be honest with themselves that genetic concerns of students may be above them and should therefore refer such cases to the appropriate quarters like the hospitals where there are professionals like clinical psychologists, genetic counselors, and gynecologists to handle them well.

\section{Theoretical Framework/ Review}

This study was based on the principles of person-centered and social learning theory. The person centered theory emphasizes on the human interaction between two people (the counselor and the client, in this case). Social learning theory, on the other hand, postulates that a child learns behavior through social interaction in the form of observation and imitation of what other people in the society are doing (Ndirangu, 2017).

\section{Person-Centered Theory}

This theory focuses on the human interaction between the counselor and the client. Rogers (1967) called it the Person-centered or client-centered theory in order to suggest that his principles extended beyond the client-therapist relationship to encompass all human interaction. The current person-centered theory is understood as a process of helping clients discover new and more satisfying personal meanings about themselves and the world they inhabit. The student will drive towards growth, health and adjustment (Makinde, 1984) as cited in (Ndirangu, 2007). The model assumes that human interaction is only possible when certain conditions prevail. In the case of guidance and counseling, these conditions should prevail counselor's demonstration in the counselor-client orientation. According to Omulewa (2000), these conditions include counselor's demonstration of empathy, unconditional positive regard and warmth to the client. He notes that growth occurs in an acceptable, warm, empathetic, non-judgmental environment that allows students the freedom to explore their thoughts and feelings and to solve their own problems (Ndirangu, 2007).

Guidance and counseling programme that lacks these characteristics culminate into poor performance of students in school. When a counselor communicates the above conditions, those being helped will become less defensive and more open to themselves and their world and they will behave in more social and constructive ways. Many students harbour feelings of failure in academics and thus have low self-esteem, but a counselor is able to counter the feelings by working towards fostering the students' capacity to hope 
and believe that they are capable of overcoming academic failure they are experiencing and even end up performing their best potentialities (Ndirangu, 2007). A conducive environment for the student should be provided and teachers should provide room for self-actualization by being friendly, loving, competent and responsible. Teacher counselor should also help the student set goals and allow positive self-recognition after attaining set goals and aspirations that will boost success in academic performance. Therefore, a good environment should be created by teacher counselor (Ndirangu, 2007).

\section{Social Learning Theory}

Learning is a process where behaviours are learnt or acquired from the environment. One way of learning is through social observation and imitation. This theory is advanced by Albert Bandura (1977). This theory explains delinquency as a behavior learnt through the complex process of socialization. The theory postulates that the behavior is reflective of people observing and imitating others and imagining the consequence of their own behavior. The theory advocates that human behavior is modified using learning principles to change behavior (Omulema, 2000) as cited in (Ndirangu, 2007). The behavioral approach emphasizes that the client defines goals in behavioural terms provide resources and encouragement in helping clients more towards goals and helps clients with different problems (Patterson, 1973). Teacher counselors can therefore apply this in counseling students concerning their academic performance. Makinde (1984) notes that counseling effectiveness and outcome of counseling are assessed by change in the specific student's behavior. This implies that counseling can use behavioural counseling to create a conducive environment for the students to modify their behaviors in order to solve their academic problems through creation of learning conditions. Teacher counselors can use behavioral techniques like self-management programmes and self-directed behaviors which may deal with learning, study and time management skills in schools. This will foster the students' academic performance. The student will drive towards growth, health and adjustment (Makinde, 1984). Therefore, a good environment created by the teacher counselor can provide room for good self-concept that will boost success in academic performance (Ndirangu, 2007).

\section{Conceptual Framework}

The theoretical framework assisted in the conceptualization of this study to show the relationship between guidance and counseling and academic performance of the students. The study conceptualized that all colleges of education in the country had established guidance and counseling programme to offer orientation, appraisal, educational/career, counseling and placement services to students (independent variable). The programme is supposed to assist students to harmonize their abilities, interests and values and thereby develop their full potential. All these activities and services are geared towards improving the selfimage of the students and facilitate better achievement in academic performance (dependent variable). Academic performance of students in a school is determined by very many factors including the ability of the individual student, the quality of the teachers, the availability of facilities, and guidance and counseling, among others. The actual influence of guidance and counseling programme on the academic performance of the student is in turn given chance to be assessed when other factors like extraneous and intervening variables which can influence the behavior of the dependent variable or the outcome of the study were put under check (Ndirangu, 2007). The interrelationships are illustrated in figure 1 which guided this study. 
Independent variables

intervening variables

Dependent variable

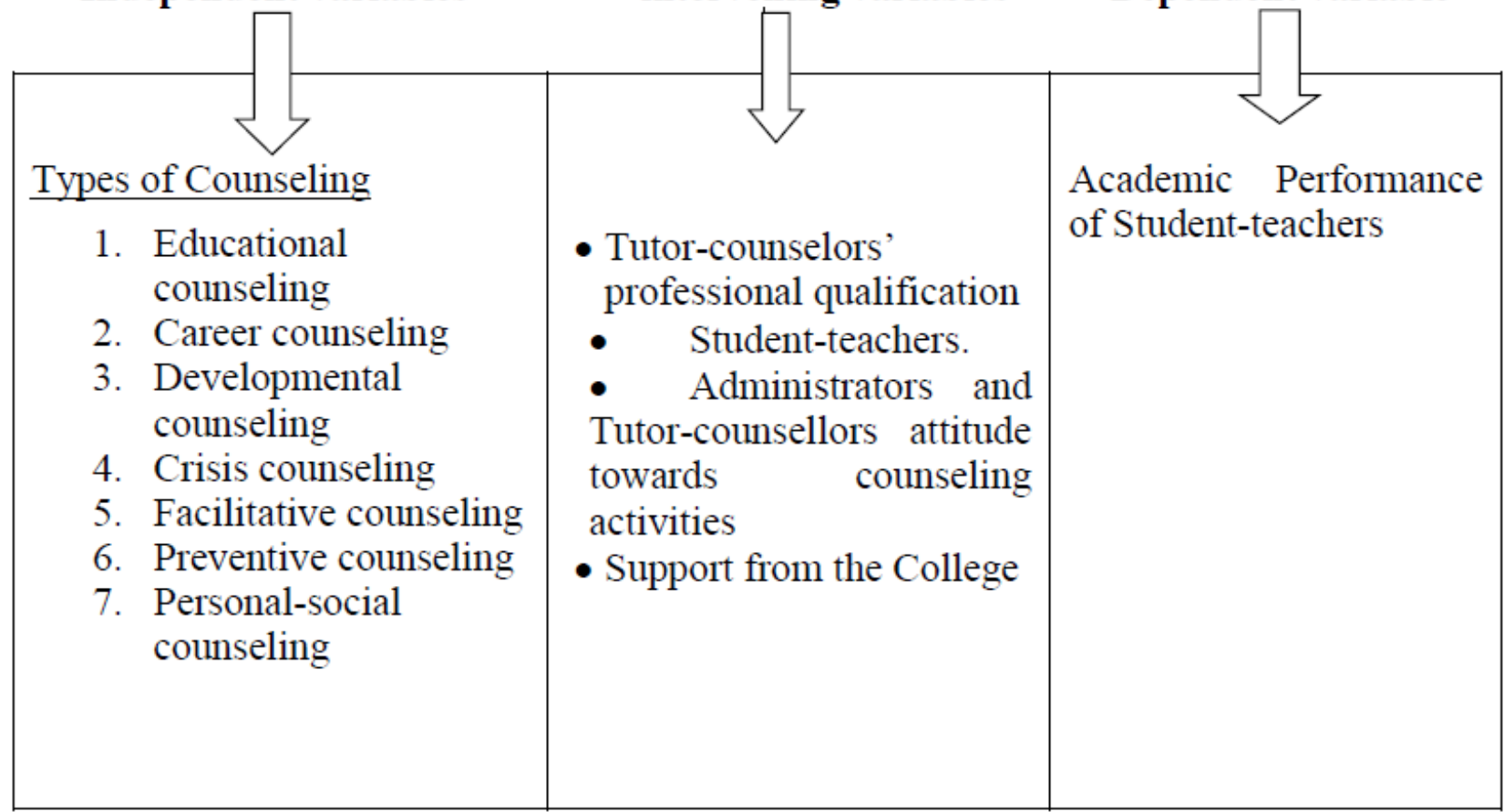

Figure 1: Relationship Between Types of Counselling and Academic Performance of Student-teachers

\section{Research Design}

Research Design is a crucial part of the study since it provides the framework on how to achieve the research objectives and answer the research questions (Atise,2013). The researcher employed the qualitative approach with case study in focus. Strauss and Corbin (1998:10-11) cited in Badu-Nyarko (2011) defined qualitative research as "any type of research that produces findings not arrived at by statistical procedures or other means of quantification". It can infer to research about persons' lives, lived experiences, behaviors, emotions, and findings as well as about organizational functioning, social movements, cultural phenomenon, and interactions between nations. Some of the data may be quantified as with census or background information about the persons, or objects studied, but the bulk of the analysis is interpretative. The researcher has settled on the qualitative research design because he wants to find out from people their understanding of how counseling services affect their lives at their school and workplace. The qualitative research design strength lies in the fact that researchers are able to get in-depth information about the research problem resulting in a fuller understanding of such an issue or phenomenon by all and sundry. However, the design has a weakness of the likelihood of a researcher infiltrating his personal prejudices into the recording of the data on the issue under study. Case study is a form of qualitative analysis involving a very careful and complete observation of a person, a situation or an institution. It probes deeply and analyses interaction between the factors that explain present status or that influence change and growth (Kulbir,2011). The researcher is adopting case study as one of his research designs for the simple reason that the current study will probed into the true and comprehensive picture of the individuality of E.P. College of Education, Bimbilla, on the issue of how the counseling service affect student-teachers' academic performance.

\section{Population and Sampling}

Population is the group of interest to the researcher. Kumekor (1995) described population as the empirical units such as objects, subjects, occurrences etc used for a study. The target population for this study was all students in the Nanumba North district. The accessible population was students of E.P. College of Education, Bimbilla. Considering the challenge of high student-population of 500 which comprises of 270 second year students and 230 first year students, the researcher selected some number of students to be participants of the research. Sampling is the technique used in selecting a homogenous unit from the population to be part of the study. According to Ezeliora and Jude (2011), sampling becomes necessary when the population is large and cannot be reached readily. This involves defining the population, listing the units of the population, determining the sample size and drawing from the list. The important thing is that characteristics of selected participants should enable the researcher to make statistical generalization. 


\section{Sampling technique and sample size}

The researcher used the stratified random sampling technique in selecting the sample of the study. The stratified sampling technique involves dividing the population into a number of homogenous groups or strata. Each group contains subjects with similar characteristics. A sample is then drawn from each group of stratum. The division of the population into strata or homogenous group is based on one or more criteria, example, sex, age, professional status and so on. The researcher intended to use the stratified sampling technique because the units of study were uniformly distributed, for instance, views/responses were taken from the students, the principal, and the college's counselors. The researcher used the purposive sampling technique to select participants like the college's principal and the college's assessment officer for the simple reason that the two personalities have unique characteristics or expertise related to the study (Arthur,2012). In addition, the researcher used the simple random sampling technique to select the number of students who became participants of the study. The researcher did this by writing 'YES' or 'NO' on pieces of papers. He then folded the papers and put them in a small box and allowed both first and second year students to picked one folded paper from the small box. The researcher then accepted students who picked a folded paper with 'YES' written on it as participants of the study. The simple random sampling technique was chosen in order to allow all the students in both first and second year have equal chances of being selected as participants of the study. The sample size is the number of representatives of the larger population who share similar characteristics. The sample size of the study is 250 students, a vice principal, an assessment officer, and three college counselors. The study's sample size of 250 out of 500 students according to the school register represents $50 \%$ of the student population. This will allow for different views to be collected and analyzed.

\section{Instruments for Data Collection}

The researcher collected primary data through administration of three sets of questionnaires (students, tutor counselors, and the assistant head of the institution). According to Babbie (1998), a questionnaire is a series of questions or instruments specifically designed to elicit information that will be useful for analysis. There are three types of questionnaires; structured, semi-structured and unstructured. The current study made use of semi-structured questionnaire consisting of closed ended and open ended questions. The three separate questionnaires used by the researcher were adopted questionnaires by Ndirangu Prisca Njeri (2007). The researcher, however, modified them a little to suit the current study. On the other hand, the three separate interview guides were rather designed by the researcher himself. The semi-structured questionnaire that will be used in this study consists of four main parts. Part A elicited information on the perception of studentteachers of the role of the counseling service. Part B sought information on the contribution or impact of the counseling services to student-teachers' academic performance. Part $C$ elicited information on the patronage of the counseling service by student-teachers. Lastly, Part D sought information on the types of counseling services received by student-teachers. The student questionnaire elicited information on the perception of the role of the counseling service by student-teachers, the impact of the counseling service on students' academic performance, what motivates student-teachers to patronize the counselling service and the types of counseling services received by student-teachers. The college counselor's questionnaire sought information on the operation of the guidance and counseling programme, his/her professional qualifications, experience, support from the administration and teachers, and the challenges the guidance programme is facing in the college. The head of the institution questionnaire elicited information on the guidance programme, mode of selecting/appointing the counselors, academic performance of the school, factors affecting academic performance, support given to the guidance programme, among others. In addition to the use of the above questionnaires, the researcher designed three separate interview guides to collect information from the sample, that is, the student-teachers, the college counsellors and the vice principal. The questions used for the interviews centered on the research questions. Both the questionnaires and interview guides were used for triangulation purposes.

\section{Pilot Study}

The researcher pretested his instruments on some selected students of a population of 50 in the targeted college. Again, the researcher administered the questionnaires designed for the student-teachers, tutorcounselors, the vice principal, in another College of Education in the Yendi Municipality. This exercise 
made the researcher well informed about the validity of questions he would asked the real respondents and became aware of whether the wording and format of questions could pose any difficulties.

\section{Data Collection Procedures}

The researcher collected a letter of introduction on his research activity from the department of Psychology and Education, University of Education, Winneba. This letter was presented to the college authorities in E.P. College of Education, Bimbilla. The College authorities gave the researcher the chance to collect data from the sampled population which comprises of student-teachers, tutor-counselors, and the Vice Principal all of the College. The letter of introduction was also presented to the authorities of the institution where the pilot study was done before the data was taken there.

The researcher collected primary data from the students, the vice principal, and the college counselors. The researcher sought permission from the college authorities before going ahead to administer the questionnaires in the various lecture rooms. The questionnaire administration was done by the researcher with the assistance of some college tutors as he visits the various lecture rooms and got students to respond to the questionnaire items. The researcher also gave questionnaires to the vice principal, the school counselors and gave them some time to complete them. The researcher later went back to these college officers for his questionnaires.

\section{Data Analysis}

The data collected was processed, coded and analyzed to facilitate answering the research questions. The researcher used descriptive statistics to describe the characteristics of the sample population. Inferential statistics were used in making deductions and generalizations about the whole population.

\section{Ethical considerations}

The researcher informed the college authorities about his intention of conducting the study in the college by presenting his letter of introduction to them. The researcher also assured the college authorities and other members of the college community involved in the research (the respondents) that his research is purely academic and that any information elicited from them will be kept confidential. Interviews conducted by the researcher were done in a confidential manner and at a professional setting with the aim of making respondents open up and divulge the right information to the researcher. The researcher also assured the respondents that the conduct and outcome of the research will not inflict physical, emotional or any form of harm to them.

\section{Main issues (The vice Principal)}

Research question one: What are the student-teachers' perceptions of the roles of counseling service in E.P. College of Education, Bimbilla?

The first research question of the study was geared towards finding from respondent the student-teachers perceptions of the roles of counseling service in E.P. College of Education, Bimbilla. As part of this, the Vice Principal was asked to express his views on issues on the following themes and sub-themes regarding the roles of counseling service in E.P. College of Education, Bimbilla. The data gathered from the interviews were as follows: According to the Vice Principal "the roles of counseling service in E.P. College of Education, Bimbilla, cannot be overlooked since it is the core factor for discipline to be attained. He further said the role of counseling service is very vital for good performance as a result of good discipline emanating from it. He was of the view that Guidance and counseling services have enabled students in the college to be well disciplined with improved academic performance. The school administration determines the discipline on students in the college because the level of counseling service offered depends on the interests and concern of the principal towards the said services in the college". He is of the view that most students and even staff in this college, still think that counseling is for those with problems, the criminals, those who are not doing well in class. Counseling is stigmatized as in it is for people who have problems that seek counseling. He also stated that "one of the roles of guidance and counseling officers like the teachers is to advise students on matters of education and other skills. According to him, the guidance and counseling officer advises the College on matters concerning students' welfare and how the College and students are to relate. Through guidance and counseling comprehensive advice on career or courses is given to students". 
He indicated that "teachers are supposed to assist their students, for example, in choosing elective subjects, programmes, and making adjustments in the College. Again, he further stated that guidance and counseling officers most often prescribe disciplinary actions for students who flout College rules. Punishments are prescribed for students to let them feel sorry for their action(s) but not to deter them from College or their careers". The Vice Principal stated that "guidance and counseling was not widespread among students in the college. Students do not patronize the services of guidance and counseling unit in the College. Most students are shy to approach the counselors for advice in relation to their problems or challenges. Most students are ignorant of the services provided by the guidance and counseling units. Most of the students preferred to share their problems with their colleagues rather than share it with those at the guidance and counseling office".

He further said that "When guidance and counseling is introduced to students, chances of having problems with behaviours management diminish as more of the students have the opportunity to decide how they learn. Through guidance and counseling services there are less personal problems among the students in the College. Guidance and counseling is not only better provided by competent tutor-counselors but even by other tutors". The vice principal is of the view that some teachers in the college support the department through consultation and referring students with problems to the tutor counselor(s). Again the college does not involve parents or guardians of the students in the counseling. Hence, parents do not also support the work of the tutor-counselors. He further stated that the college has three trained tutor-counselors. The college sometimes organizes seminars and invites guest speakers to educate both teachers and students on the need to patronize counseling services. The school administration also supports the department but it is inadequate. There is more room for improvement.

Throwing more light about the student-teachers perceptions of the roles of counseling service in E.P. College of Education, Bimbilla, the Vice Principal interviewed had this to say:

"Some students do not believe that the college makes use of their continuous assessment, so they don't attach seriousness to it. Through guidance and counseling talks we tell them about the nature of their examination and the need to take their continuous assessment seriously so that they can pass their examinations easily. Besides, any time the college releases results, the principal invites me and the two other tutor-counselors. We analyze the results to see the performance of students. Usually, interventions are put in place to address the issue of students that performed poorly. Students who record many trails are invited to the counseling unit and attended to, such students are taken through study skills, how to manage examination anxieties among others". The findings support Abdulai and Inkoom (2016) who examined the role and place of guidance and counseling in Early Childhood teacher training. According to them, guidance and counseling services should be mandatory on the part of students and that such services should not be limited to academic issues but should also address personal and social needs of recipients. The findings also support Gatua, Sindabi, and Chepchieng (2015) who conducted a study on the impact of Guidance and Counseling services on students' behavior modification between selected public urban and rural secondary schools in rift valley province, Kenya. It was concluded that guidance and counseling services in secondary schools help in modifying students' behavior in social and emotional adjustments. Guidance and counseling services enabled students to be well disciplined with improved academic performance.

Research question Two: What is the impact of counseling services on student- teachers' academic performance in E.P. College of Education, Bimbilla?

The Vice Principal stated that "guidance and counseling has positive results and that it helps shape the moral life of students when the proper counseling is given. It enables students to make the right choices in terms of programme selection and dealing with challenges that students have with their peers. According to him, counseling service helps students to adjust and cope with school life. Counseling service is sometimes designed for academically poor students only." He further stated that "most tutor-counselors have great interest in the good academic achievement of the students than in any other area. He said counseling is also offered as it promotes peace of the mind to create good chances for concentration in learning. According to him, it is vital that every school principal should identify the main services that need to be offered and dwell in them for the purpose of producing students who are disciplined and visionary in life". He was of the view that "through counseling, some of the students changed their habits in relation to the way they have been 
shown to become more aggressive in learning and also studying their lessons". In terms of their academic performance in the school, the vice principal rated it as very good. According to him, "counseling service has made students more responsible of their academic work. Counseling service provides students with information on the available career opportunities. Counseling services assist students on how to choose their subject combinations".

The vice principal was of the view that Guidance and counseling services:

1. Help students solve educational, personal and disciplinary problems

2. Guide students to develop good study and time management skills

3. Prepare students adequately for their Out Segment Programmes and

4. Counsel students who are academically weak and record many trails or referrals.

For me, guidance and counseling services are beneficial to students. I say so because of the role guidance and counseling services play in the school system. For instance, guidance services are relevant to the academic, social, emotional and career development of students. Counseling helps students solve their personal, social and academic problems before they get out to the public domain for everybody to feed in their perceptions on such issues. Even though we give students orientation about what to do and not to do, when the students go to the communities for their out segment (teaching practice), they face a lot of challenges. A lot of issues arise when they are in their communities. There is a village where some members of the community had problems with one of our female students. In fact, the guidance officer stepped in to resolve the problem amicably. He went there several times with the teaching practice coordinator. The findings support Atise, (2013) who said that academic counseling includes helping students to acquire skills, attitudes and knowledge that contribute to effective learning in school; employing strategies to achieve success in school and understanding the relationship of academics to the world of work and to life at home and in the community. He reported that students who utilized guidance and counseling services performed better than those who did not. The finding was in line with Atise, (2010) who argued that the contribution of counseling service helps an individual to gain an understanding about himself or herself and fosters the development of skills to be used in dealing with difficulties associated with personal, academic and social life.

Research question Three: What motivates student- teachers to patronize the counseling service in E.P. College of Education, Bimbilla?

According to the Vice Principal, "the guidance and counseling services in the college address the needs and concerns of students or learners at different levels of academic or educational development". He also stated that "Counseling services in the college is designed to help students understand and clarify personal views of their life space and to learn to reach their self-determined goals through meaningful, well-informed choices and a resolution of problems of an emotional or interpersonal nature. He believes that every human individual has the potential for self-growth, self-development and self-actualization" He said that "it is through guidance and counseling that school administrators can manage discipline to students. Discipline is a rudimentary ingredient that plays a crucial role in school system and insists on upholding the moral values of students. It is intended to suppress, control and redirect behaviour. According to him, the college has a track record of instilling discipline, and guidance and counseling services have enabled students to be well disciplined with improved academic performance."

He also said that "Counseling services in the college help students to cope with examination anxiety. The fear of failure and the craving for the highest grades are major sources of pressure among students. It helps students to develop effective study habits. The students are assisted to improve their competence in reading, note-taking, and academic achievement. It provides students with meaningful educational experiences. The students are able to relate the curriculum to occupational groups". The finding is in line with Nam et al. (2010) who said that female students who are faced with emotional, academic, psychological, financial, and marital problems are more likely to discuss their issues with someone with the aim of finding a lasting solution to their problems. He concluded that female students are highly motivated to patronize the counseling service. The findings also support Johnson (1987) that Students classified as feminine were more 
confident in professionals' ability to help with personal problems and, along with androgynous students, were more willing to recognize a personal need for help. As such they patronize the counseling service.

\section{Background information of Respondents (Tutor-Counselors)}

From the analyzed data it was found that educational level and personal characteristics of school counselors positively impacted on the delivery of guidance and counseling services in the college. Most of the school counselors were males in the age bracket of 44-53 years, also male teachers were dominant than female teachers and all agreed that guidance and counseling was important in the college. The age factor influences the good relationship between tutors and students thus creating a cordial discharge of guidance and counseling services. From the study, 4 tutor- counselors were interviewed. They are professionally trained as tutor-counselors. Most of the counselors had attained masters' degree and hence could easily guide their students. With regards to their years of teaching experience, most of them have been in the teaching field for over twenty-three years, only one tutor counselor had nine years teaching experience and with the number of years as tutor- counselors, they have served for more than six years. It is expected that through their experiences, they can easily administer and offer guidance and counseling services to students adequately. They require experience to obtain information from students through cordial and friendly approaches. Counseling should be a noble call and as forwarded by the respondents, before an individual enters the counseling profession they should have a strong love and passion for learning as well as sharing it with the students. One should be able to adequately enjoy working and relating to a certain age group of students. Tutor Counselors should be encouraged to advance in their academic grades by enrolling in institutions of higher learning for further studies.

\section{Main issues (Tutor-Counselors)}

Research question one: What are the student-teachers' perceptions of the roles of counseling service in E.P. College of Education, Bimbilla?

According to the first tutor- counselor, "being a Counselor I must always introduce new ideas to students on educational matters. He also said that "I must always encourage students to discover new ways of doing things". Most of the students faced a lot of challenges, being it academics or social issues. There is the need to introduce counseling service to them at any level of their educational ladder. This might push them to manage their time and perform well in class. Some of them prefer sharing their problems with peers. Few do not patronize our counseling services; the fear is that their problems would be discussed among the tutors and other tutors might use it against them or may mock them. The second tutor-counselor was of the view that "as a Counselor, I will always introduce new treatment techniques. I will also encourage students to always read far and wide reports of researchers carried out in journals". The third tutor-counselor said that "under the orientation services of guidance and counseling, I will encourage students to receive information on rules and regulations of the college and I will also support the department to organize orientation for students who come into the college for the first time. I will also encourage the students to receive information on daily functions of the college and also go on field trips". The tutor-counselors were of the view that the orientation services are planned to assist both new students and staff get acquainted with their new school, adapt to their new environment and the people in it. According to the fourth tutor-counselor, "students must be provided with information on physical changes in their body; I will ensure that students receive information on the best way to develop friendship with peers; I will help students to become aware of the many occupations to consider after leaving college and provision of information on existing job vacancies."

According to the tutor-counselors, it is important that the school authorities provide necessary facilities and resources to the counseling department in the college. They are of the view that the main administrative roles of the school authorities in delivering guidance and counseling services in the college are facilitating the workshops of the H.O.D, budget for the department during school budget, appoint and motivate tutorcounselors. But it is rather sad that the school administration does not support the department. The kind of services offered by guidance and counseling programme in the college is that of the educational counseling services. The tutor-counselors were pleased with the support from other colleagues' tutors who refer students with problems to them. Some students are aware of the existence of the guidance and counseling department. Others too don't patronize the counseling services. The most common counseling issues among 
students are psychological problems such as relationship issues, academic problems, personal and family issues. The teachers said that they adequately addressed these issues. At times they involved the parents or guardian of such students. And these parents also support our work as tutor-counselors. Most students let themselves be guided and be influenced by someone who understood them, listened to them and to some extent their friend. Guidance and counseling was important in students' career prospects. This suggested that few students would seek for counseling on career choice and make right career choices. The findings support Carkuff (1983) that in facilitative counseling, the counselor assists the students through the cyclical process of exploration, understanding and action. He further opined that the concern areas of facilitative counseling include making and choosing academic options, planning and choosing a career, family growth and relationship, identifying individual strengths, interests, aptitudes, abilities and many other areas. Indeed, most day-to-day counseling activities and concerns in school settings especially are facilitative in nature. The findings also support Abdulai and Inkoom (2016) who examined the role and place of guidance and counseling in Early Childhood teacher training. According to them, guidance and counseling services should be mandatory on the part of students and that such services should not be limited to academic issues but should also address personal and social needs of recipients. Havinghurst (1980) opined that developmental counseling helps the individual learn how to achieve healthy growth in society. Thus, counselors can through this process aid individual at all age levels and whole-heartedly support them in overcoming their developmental tasks. Hoose and Worth (1982) opined that counselors with an understanding of developmental psychology can effectively aid students as they progress through various stages and transitions in their development.

Research question Two: What is the impact of counseling services on student- teachers' academic performance in E.P. College of Education, Bimbilla?

All the tutor-counselors indicated that guidance and counseling services were offered in the college especially for educational matters. In most of the college, guidance and counseling is offered for specific reasons. The main ones are educational purpose and solving personal problems that may hinder the attainment of academic excellence. The tutor-counselors also associated career achievement with the school programme and were ready to counsel students on career related issues, on career choice, career compatibility and on different work environments. Their responses could be attributed to the level of knowledge, training, personal experiences and a degree of exposure. Therefore, tutor-counselors had to realize the need of passing on career information to their learners to enable them make right career choices and have high career expectations. The first tutor-counselor agreed that "through guidance and counseling comprehensive advice on career is given to students. The first tutor-counselor agreed that through guidance and counseling services there are less personal problems among the students. The first tutor-counselor was of the view that guidance and counseling services had enabled students to be well disciplined with improved academic performance". The second tutor-counselor said that "most of the students benefited from guidance and counseling in problem solving. Some of the students benefited from guidance and counseling and improve upon their learning process and reading skills. Others had stable relationship which contributed to good academic performance. According to him, most of the first year students performed above average, because they were involved in counseling service". According to the third tutor-counselor, "Guidance and counseling services influence students' academic achievement positively in the college. The second year students performed very well in class assignment and exams, they were well disciplined and they listened to instructions and participated fully in class discussions". The fourth tutor-counselor is of the view that "there is a significant difference in the academic achievement of students exposed to guidance and counseling services in the college and those not so exposed. According to the tutor-counselor, "I do a lot of follow up services and ensure that students live up to expectation".

According to the tutor-counselors, "counseling service has made students more responsible of their academic work. Counseling service provides students with information on the available career opportunities. Counseling services assist students on how to choose their subject combinations". From the study, it was indicated that tutor-counselors agreed that guidance and counseling services were offered in the college were vital for good performance as a result of good discipline emanating from it. Two tutorcounselors had these to say to indicate the kind of guidance and counseling services they render to students in the college: "As part of preparing our students to face the outside world of work, the counseling team 
normally organizes seminars where we invite officials from Ghana National Association of Teachers (GNAT), Social Security and National Insurance Trust (SSNIT) and from other institutions. The GNAT officials usually enlighten students about the teaching professions whereas the SSNIT people will talk to students about the need for employee enrolment in pension schemes. Counseling services are daily, we can get one or two students, but that is after classes. Both male and female students come but the females come more than their male counterparts. We cannot tell whether there is a special reason but the female students want to discuss more about their future and marriage."

Throwing more light about the contribution of guidance and counseling services to students in the college, two out of the four tutor-counselors interviewed had this to say:

"Guidance and counseling services are useful to students in terms of their academic, personal and social issues. To help our students achieve these benefits, they are put in groups and assigned to tutors who are more experienced in life and academics to guide them. The tutors meet their students regularly to discuss problems that may hinder students learning and welfare in general. However, when emotional and psychological issues arise they refer them to us and collaborate with us to resolve or manage such issues" The findings support Atise, (2013) who said that academic counseling includes helping students to acquire skills, attitudes and knowledge that contribute to effective learning in school; employing strategies to achieve success in school and understanding the relationship of academics to the world of work and to life at home and in the community. He reported that students who utilized guidance and counseling services performed better than those who did not. The finding was in line with Atise, (2010) who argued that the contribution of counseling service helps an individual to gain an understanding about himself or herself and fosters the development of skills to be used in dealing with difficulties associated with personal, academic and social life.

Research question Three: What motivates student- teachers to patronize the counseling service in E.P. College of Education, Bimbilla?

According to the first tutor-counselor, guidance and counseling was offered for solving personal problems in the college. This shows that the main aim for guidance and counseling in mixed boarding school such as E.P College of Education, Bimbilla, is for good academic achievement and discipline that enhances conducive environment and synergy among students that will eventually promote learning. According to him, psychological and social guidance is also offered as it promotes peace of the mind to create good chances for concentration in learning. It is vital that every tutor-counselor should identify the main services that need to be offered and dwell in them for the purpose of producing students who are disciplined and visionary in life. Further, he said that:

"I visit students after counseling sessions and also visit students after resolution of their problems. According to him, Counseling services assist students on how to choose their subject combinations".

The second tutor-counselor said that: "Counseling services do assist students to develop good study habits". According to him, "Counseling services provide students with information on the available career opportunities". Students would seek for counseling on career choice and make right career choices. It is imperative for tutor-counselors to be role models as it is considered a good feeling when students view them as role models. Studies have indicated that many students who have been counseled by teachers do change their habits of behaviour when they are shown the way. It is good to note how some of the students changed their habits in relation to the way they have been shown to become more aggressive in learning and also studying their lessons. Teachers should also show concern and love to the students for they are like parents who are supposed to nurture their children with parental love.

The third tutor-counselor also said that: "Counseling services have made students more responsible of their academic work". According to him, Counseling services do assist students in their time management. For guidance and counseling to be effective in the college quality time was needed. It was also noted that the schools with intense services of guidance and counseling performed best in academics. He also said that "Counseling services in the college help students to cope with examination anxiety". Guidance and counseling is important in discipline observance. It is therefore vital for the college to embrace guidance and counseling since many students face difficulties in problem solving such as laziness, boy/girl relationship, 
drug and substance abuse. The fourth tutor-counselor is of the view that "Counseling services help students to adjust and cope with school life. Most students acknowledged the usefulness of guidance and counseling in their school life. It provides students with meaningful educational experiences. The students are able to relate the curriculum to occupational groups. The guidance and counseling services in the college address the needs and concerns of students". The findings support Atise, (2013) who reported that students who utilized guidance and counseling services performed better than those who did not. The finding was in line with Atise (2010) who argued that the contribution of counseling service helps an individual to gain an understanding about himself or herself and fosters the development of skills to be used in dealing with difficulties associated with personal, academic and social life.

\section{Background information of Respondents (Students)}

From the analyzed data it was found that most of the students were males in the age bracket of 20-30 years, whiles the female students were in the age bracket of 20-27 years, also male students in the college were dominant than female students and all agreed that guidance and counseling was important in the college. It is evident that the students are youthful and may have varied expectations in life. Some of their needs at their level of education could include preparing adequately for their career as teachers, entering marital life, being anxious about the various regions, districts, towns and villages they will be posted to after their completion, among others. It is therefore necessary for the college to provide guidance and counseling services to address their varied needs to prepare them adequately for the teaching profession. The data also show that 150 respondents (representing 60\%) of the study population were males while 100 (representing 40\%) were females. This clearly shows that there were more male participants than females in this survey and it may be the result of the sampling technique used in selecting respondents. 250 students responded to the questionnaires, making a response rate of $98 \%$. This reasonable response rate was achieved after the researcher made personal calls and physical visits to remind the students to fill-in and return the questionnaires. Due to the good response by the respondents the data collected was adequate for analysis and results obtained dependable.

\section{Main issues (Students)}

Research question one: What are the student-teachers' perceptions of the roles of the counseling service in E.P. College of Education, Bimbilla?

Five statements were put forward to assist the researcher in assessing the student-teachers' perceptions of the roles of counseling service in E.P. College of Education, Bimbilla. Each statement was scored on a 5point scale strongly agree (SA), agree (A), not sure (NS), disagree (D), or strongly disagree (SD). The researcher came up with the findings as indicated in the table below:

Table 1: The Perception of student-teachers on the role of the counseling service in E.P. College of Education, Bimbilla $N=250$

\begin{tabular}{|l|l|l|l|l|l|}
\hline Statement (s) & SA F (\%) & A F (\%) & NS F (\%) & D F (\%) & SD F (\%) \\
\hline $\begin{array}{l}\text { My school counselors most often } \\
\text { prescribe disciplinary actions for } \\
\text { students who flout school rules }\end{array}$ & $100(4)$ & $150(60)$ & - & - & - \\
\hline $\begin{array}{l}\text { My school counselors are } \\
\text { knowledgeable enough to help me } \\
\text { make good career choice }\end{array}$ & - & $200(80)$ & - & $50(20)$ & - \\
\hline \begin{tabular}{l} 
My school counselors treat \\
\hline
\end{tabular} & $50(20)$ & $150(60)$ & - & - & \\
\hline
\end{tabular}




\begin{tabular}{|l|l|l|l|l|l|}
\hline $\begin{array}{l}\text { me as a unique person } \\
\text { My school counselors prompt } \\
\text { in providing me information } \\
\text { when I request }\end{array}$ & - & $200(80)$ & - & & $50(20)$ \\
\hline $\begin{array}{l}\text { My school counsellor is trustworthy } \\
\text { enough to discuss my career decisions } \\
\text { with }\end{array}$ & $100(4)$ & $150(60)$ & - & - & - \\
\hline
\end{tabular}

Source: Researcher's fieldwork (2020)

From the Table 1, the data showed the responses from the students on the student-teachers perceptions of the roles of counseling service in E.P. College of Education, Bimbilla. From the table 1, (100\%) of the students agreed to the first statement that my school counselors most often prescribe disciplinary actions for students who flout school rules. No students disagreed or not sure. In relation to my school counselors are knowledgeable enough to help me make good career choice, $80 \%$ of the students agreed to the statement and $20 \%$ disagreed. Concerning my school counselors treats me as a unique person, $80 \%$ agreed and $20 \%$ disagreed. With the issue of my school counselors prompt in providing me information when I request, $80 \%$ agreed and $20 \%$ disagreed. With my school counsellor is trustworthy enough to discuss my career decisions with, it has been identified that $100 \%$ of the students agreed and no students disagreed. According to the students, the guidance and counseling services in the college address the needs and concerns of students at different levels of academic or educational development. The students were of the view that Guidance and counseling was important in their career prospects. Most students were aware of guidance and counseling services in the college. The students agreed that counseling service helps them in career choices.

Highlighting on the role of guidance and counseling services to students in the college, two students made the following comments:

The first student said that: "I know guidance and counseling is important to students especially first years. For instance, they are new and need guidance to help them become familiar with the college environment which might be new to them and different from their senior high schools. Again, guidance and counseling is not only for our academic pursuit, but inculcate in us good morals and develop our spiritual life so that we could be useful to the society after completion". The second student said that: "I think guidance and counseling is important because it helps us to address our social and personal issues. When you have a problem you can go to the counselor on one-on-one-to get advice. Besides, in this college, we are kept in groups and assigned to teachers. They give us lots of advice about our life style and behaviour on campus and how to improve upon our academic work. Because this is an institution student can marry and the females who are married can get pregnant. When female students are pregnant they can seek the advice of the counselor so as to defer their courses or programmes or otherwise".

Some students were of the view that, guidance and counseling deals with almost every aspect of a student's life. Because at one point, may be an issue is raised in the news, social aspects like pregnancy, girl boy relationship, what is happening at home, relationship between parents and youths, and so on. The findings support Carkuff (1983) that in facilitative counseling, the counselor assists the students through the cyclical process of exploration, understanding and action. He further opined that the concern areas of facilitative counseling include making and choosing academic options, planning and choosing a career, family growth and relationship, identifying individual strengths, interests, aptitudes, abilities and many other areas. Indeed, most day-to-day counseling activities and concerns in school settings especially are facilitative in nature. Havinghurst (1980) opined that developmental counseling helps the individual learn how to achieve healthy growth in society. Thus, counselors can through this process aid individual at all age levels and wholeheartedly support them in overcoming their developmental tasks. Hoose and Worth (1982) opined that counselors with an understanding of developmental psychology can effectively aid students as they progress through various stages and transitions in their development. 
Research question Two: What is the contribution of counseling services to the student- teachers' academic performance in E.P. College of Education, Bimbilla?

Table 2: The contribution of counseling services to the student-teachers' academic performance in E.P. College of Education, Bimbilla. $N=250$

\begin{tabular}{|c|c|c|c|c|c|}
\hline Statement (s) & SA F (\%) & A F (\%) & NS F (\%) & D F (\%) & SD F $(\%)$ \\
\hline $\begin{array}{l}\text { It results in good grades or } \\
\text { performance }\end{array}$ & $150(6)$ & $100(40)$ & - & - & - \\
\hline $\begin{array}{l}\text { It enables students to interaction } \\
\text { well with teachers and lesson } \\
\text { content }\end{array}$ & $100(4)$ & $150(60)$ & - & - & - \\
\hline $\begin{array}{l}\text { It guides students to develop good } \\
\text { study and time management skills }\end{array}$ & - & $250(10)$ & - & - & - \\
\hline $\begin{array}{l}\text { It does encourage self - directed } \\
\text { and independent learning } \\
\text { Some learners' attention is very } \\
\text { high and active in the learning } \\
\text { activities }\end{array}$ & $150(6)$ & $50(20)$ & - & $50(20)$ & \\
\hline & & & & & $50(20)$ \\
\hline
\end{tabular}

Source: Researcher's fieldwork (2020)

The Table 2 showed that $100 \%$ of the students agreed that good grades or performance was one of the contributions of counseling services to the students' academic performance in E.P.College of Education, Bimbilla. None disagreed. With the statement, it enables students to interact well with teachers and lesson content, $100 \%$ of the students agreed. However, none disagreed. With, it guides students to develop good study and time management skills, $100 \%$ of the students agreed and none disagreed. With, it does encourage self - directed and independent learning, $80 \%$ agreed and 20\% disagreed. Finally, learners' attention is very high and active in the learning activities, $80 \%$ agreed and $20 \%$ disagreed.

With regard to the focus group interviews held with 30 students of the college, the following contributions were identified. Guidance and counseling services:

1. Help students solve personal academic and social problems

2. Provide information to guide students especially first years

3. Help students inculcate good values and morals

4. Assist students defer course /programme of study especially females during pregnancy

5. Guide students to identify potentials and develop them

The findings support Atise, (2013) who said that academic counseling includes helping students to acquire skills, attitudes and knowledge that contribute to effective learning in school; employing strategies to achieve success in school and understanding the relationship of academics to the world of work and to life at home and in the community. He reported that students who utilized guidance and counseling services performed better than those who did not.

The finding was in line with Atise, (2010) who argued that the contribution of counseling service helps an individual to gain an understanding about himself or herself and fosters the development of skills to be used in dealing with difficulties associated with personal, academic and social life. 
Research question Three: What motivates student- teachers to patronize the counseling service in E.P. College of Education, Bimbilla

Table 3: student motivation to patronize the counseling service in E.P. College of Education, Bimbilla, $N=250$

\begin{tabular}{|l|l|l|l|l|l|}
\hline Statement (s) & SA & A & NS & D & SD \\
\hline It addresses students concerns and needs & $100(4)$ & $150(60)$ & - & - & F (\%) \\
\hline $\begin{array}{l}\text { School counsellors are trustworthy enough to } \\
\text { discuss our career decisions with }\end{array}$ & $50(20)$ & $150(60)$ & $50(20)$ & - & - \\
\hline $\begin{array}{l}\text { School counselors are friendly, nice and treat us } \\
\text { as a unique student }\end{array}$ & - & $250(10)$ & - & - & - \\
\hline $\begin{array}{l}\text { Location of counselors office are convenient } \\
\text { to ensure privacy and confidentiality } \\
\begin{array}{l}\text { School counselors assist students to develop good } \\
\text { study habits }\end{array}\end{array}$ & $150(6)$ & $50(20)$ & $50(20)$ & - & - \\
\hline
\end{tabular}

Source: Researcher's fieldwork (2020)

The Table 3 showed that $100 \%$ of the students agreed that counseling service addresses students concerns and needs and it was one of the factors that motivated students to patronize the counseling service in E.P. College of Education, Bimbilla. None disagreed. With, School counsellors are trustworthy enough to discuss our career decisions with, $80 \%$ of the students agreed. However, $20 \%$ were not sure and none disagreed. With, School counselors are friendly, nice and treat us as a unique student, $100 \%$ of the students agreed and none disagreed. With, Location of counselors' office is convenient to ensure privacy and confidentiality, $80 \%$ agreed and $20 \%$ not sure. However, none disagreed. Finally, school counselors assist students to develop good study habits $80 \%$ agreed and $20 \%$ disagreed.

Most of the students stated that guidance and counseling services could assist them develop positive attitude towards education. According to them, Counseling services provide students with information on the available career opportunities. Students would seek for counseling on career choice and make right career choices. According to them, Counseling services do assist students in their time management.

Students were of the view that guidance and counseling are useful to them in terms of their academic, personal and social issues. Most students acknowledged the usefulness of guidance and counseling in their school life. It provides them with meaningful educational experiences. Most students opined that guidance and counseling services could help them build positive self-image. It is important to note that students are of the opinion that guidance and counseling services are capable of helping them develop positive self-image towards life. The students also stated that guidance and counseling services reduce students' educational problems and make students discover occupations that suit their talents and abilities. It is worth mentioning for students to have confidence in guidance and counseling services as capable of helping them develop positive attitudes towards education. If students have positive attitudes towards education, they will be emotionally, mentally, physically and psychological ready for schooling. The findings support Atise (2013) 
who reported that students who utilized guidance and counseling services performed better than those who did not. The finding was in line with Atise (2010) who argued that the contribution of counseling service helps an individual to gain an understanding about himself or herself and fosters the development of skills to be used in dealing with difficulties associated with personal, academic and social life

\section{Summary of the Major Findings}

The summary of findings is presented based on the specific objectives of the study because the research questions that were used to guide data collection were formulated from the specific objectives. Consequently, the major findings are stated to reflect the objectives of the study. The purpose of the study is to find out the impact of the counseling service on student-teachers' academic performance in E.P. College of Education, Bimbilla, in the Nanumba North district. The research questions used include: What are the student-teachers' perceptions of the roles of counseling service in E.P. College of Education, Bimbilla? What is the contribution of counseling services to the student- teachers' academic performance in E.P. College of Education, Bimbilla? And what motivates student- teachers to patronize the counseling service in E.P. College of Education, Bimbilla? The researcher employed the qualitative approach with case study in focus. The researcher adopted case study for the simple reason that the current study probed into the true and comprehensive picture of the individuality of E.P. College of Education, Bimbilla, on the issue of how the counseling service affect student-teachers' academic performance. The target population for this study was all students in the Nanumba North district but the accessible population was students of E.P. College of Education, Bimbilla. Considering the challenge of high student-population of 500 which comprises of 270 second year students and 230 first year students, the researcher selected 250 students to be participants of the research. Four tutor-counselors and a vice principal were used for the study. The researcher used the simple random sampling technique to select 250 students who became participants of the study and used the purposive sampling technique to select the vice principal and the four tutor-counselors. The researcher adopts the use of the questionnaires and interview guides.

In line with the research questions of the study, the study indicated that counseling services could assist students develop positive attitude towards education. Most students acknowledged the usefulness of guidance and counseling in their school life. It provides them with meaningful educational experiences. Most students opined that counseling services could help them build positive self-image. It is important to note that students are of the opinion that counseling services are capable of helping them develop positive self-image towards life. The study further showed that counseling services could equip students with good study and time management skills to improve their academic performance. The implication is that students will avail themselves for counseling. If students do seek counseling, they would be assisted to develop good study skills like note taking skills, time management skills, reading strategies, examination and anxiety management techniques and how to draw personal time schedules for studies. Another finding of the study was that the students agreed that the school counselors most often prescribe disciplinary actions for students who flout school rules, the school counselors are knowledgeable enough to help them make good career choice, the school counsellors treat them as unique persons, the school counselors are prompt in providing them information when they request and the school counsellor is trustworthy enough to discuss their career decisions with. According to the students, the counseling services in the college address the needs and concerns of students at different levels of academic or educational development. The students were of the view that counseling was important in their career prospects. Most students were aware of guidance and counseling services in the college. The students agreed that counseling service helps them in career choices.

In the study, the Vice Principal agreed that the roles of counseling service in E.P. College of Education, Bimbilla, cannot be overlooked since it is the core factor for discipline to be attained. He further said the role of counseling service is very vital for good performance as a result of good discipline emanating from it. He was of the view that counseling services have enabled students in the college to be well disciplined with improved academic performance. The Vice Principal also stated that guidance and counseling has positive results and that it helps shape the moral life of students when the proper counseling is given. It enables students to make the right choices in terms of programme selection and dealing with challenges that students have with their peers. According to him, counseling service helps students to adjust and cope with school life. The vice principal was of the view that counseling services; help students solve educational, personal and disciplinary problems, guide students to develop good study and time management skills, 
prepare students adequately for their Out Segment Programmes and counsel students who are academically weak and record many trails or referrals

From the study, the tutor-counselors agreed that counseling service has made students more responsible of their academic work. Counseling service provides students with information on the available career opportunities. Counseling services assist students on how to choose their subject combinations. From the study, the tutor-counselors also agreed that counseling services offered in the college were vital for good performance as a result of good discipline emanating from it. According to them, guidance and counseling was offered for solving personal problems in the college and counseling services do assist students to develop good study habits. The teachers' counselors were of the view that counseling services influence students' academic achievement positively in the college and there is a significant difference in the academic achievement of students exposed to guidance and counseling services in the college and those not so exposed. All the tutor-counselors indicated that counseling services were offered in the college especially for educational matters. The tutor-counselors agreed that through counseling comprehensive advice on career is given to students. They agreed that through guidance and counseling services there are less personal problems among the students. The counselors were of the view that guidance and counseling services had enabled students to be well disciplined with improved academic performance.

\section{Conclusions}

Based on the findings from the study, the following conclusions are drawn: The study concluded that counseling services were provided at the college to address the needs of students. The availability of counseling services means students could enhance their self-image, social skills, leadership skills, study skills, decision making skills and work habits. The study made a laudable conclusion that counseling services could help students build positive self-image. Positive self-image enhances students' happiness, health status, and good interpersonal and social relationships among others. All these could lead to better academic performance. The study further showed that counseling services could equip students with good study and time management skills to improve their academic performance. The implication is that studentteachers will avail themselves for counseling. If student-teachers do seek counseling, they would be assisted to develop good study skills like note taking skills, time management skills, reading strategies, examination and anxiety management techniques and how to draw personal time schedules for studies. Moreover, the study revealed that counseling services exposed student-teachers to strategies to reduce anxieties in life. High levels of anxiety among students could lead to poor performance, examination malpractices, violence, truancy, and other behavioural problems. Additionally, the study reported that guidance and counseling services could improve students' knowledge about careers and job seeking skills. Another finding of the study was that the student-teachers agreed that the school counselors most often prescribed disciplinary actions for students who flout school rules, the school counselors were knowledgeable enough to help them make good career choice, the school counselors treated them as unique persons, the school counselors were prompt in providing them information when they requested and the school counsellors were trustworthy enough to discuss their career decisions with. All the tutor-counselors indicated that counseling services were offered in the college especially for educational matters. The tutor-counselors agreed that through counseling comprehensive advice on career was given to students. They agreed that through guidance and counseling services there dealt with less personal problems and more of academic issues among the students. The counselors were of the view that guidance and counseling services had enabled students to be well disciplined with improved academic performance.

\section{Recommendations}

1. There is the need for counselors to create awareness and sensitize students about the availability of the less popular guidance services such as consultation, referral and follow-up services. They could make these services popular to students through talk shows and seminars.

2. School administrators should appreciate the importance of school counselors in the college and give them the necessary support they need to discharge their duties effectively.

3. There should be general sensitization of students, parents and the general public on the importance of guidance and counseling especially as it concerns students' academic performance or achievement. 
4. To allow counselors more time to be able to provide guidance and counseling services to students, there is the need for the Ministry of Education and Ghana Education Service to formulate a policy to minimize the teaching load or exempt counselors from teaching and other responsibilities that might interfere with their responsibilities as counselors.

5. Government, Non-Governmental Organizations, Parent Teacher Associations and Old Students Unions should collaborate to provide adequate funds for the successful organization and delivery of guidance and counseling services in the college.

6. As part of making counselors offices conducive and attractive for students to access guidance and counseling services, government, principals and parents should equip counseling offices with computers and their accessories, telephone and internet facilities, sofa and executive desk. Well-furnished offices could also attract or boost the morale of trained, competent and committed counselors to give in their best.

7. To ensure privacy and confidentiality for students who seek counseling, school authorities should provide spacious offices located at convenient places.

\section{Suggestions for Further Studies}

1. A replication of this study using a wider geographical area, if possible the whole of Bimbilla.

2. Another study should be carried out in another zone like Nanumba-south, for example, so that the results can be compared.

3. Alternatively, a comparative study between the provision of guidance and counseling services in the Northern and Southern Ghana could be studied.

4. Also, it is recommended that factors that facilitate or inhibit students' willingness to patronize guidance and counseling services in the Upper East, Upper West and Northern Regions of Ghana be studied.

4. An experimental study should be carried out to establish the effectiveness of guidance and counseling services in the Colleges of Education in the Northern Sector of Ghana.

Acknowledgements: Mrs. Vida Boakyewaa Ampong, Elijah Boakye Ampong, Emmanuel Ampong Junior, Dominic Adom-Adjei, Herbert Adom- Adjei and Bridget Adom-Adjei

\section{References}

[1.] Abdulai, A., \& Inkoom, A. (2016). Guidance and counseling in early childhood teacher training. American Journal of Educational Research, 4(7) 531-538.

[2.] Ackummey, M.A. (2002). Organization and administration of school guidance programme. Accra: Media Graphics and Press.

[3.] Aluede, O. \& Imonike, J.S. (2002). Secondary school students' and teachers' perception of the role of the school counselor. Guidance and Counselling, 17(2), 46-51.

[4.] American Counseling Association (2005). ACA code of ethics. Alexandria: Author.

[5.] American Counseling Association (2007). Counseling facts sheets: Definition of counseling. Retrieved June, 20,2018 from http//www.counseling.org/Resources/

[6.] American School Counseling Association, ASCA. (2005). The ASCA national model: A framework for school counseling programs, $\left(2^{\text {nd }}\right.$ Ed.). Alexandria, VA: Author.

[7.] American School Counselor Association (ASCA) (2010). Ethical standards for school counsellors. Retrieved November,12,2017 from https://www.schoolcounseler.org/files/ethical standards 2010.pdf.

[8.] Andoh-Robertson, T. (2013). Influence of counseling on social and academic achievement of Senior high schools in the Asikuma-Odoben-Brakwa District. Unpublished thesis submitted to the Department of psychology and Education, University of Education, Winneba.

[9.] Annas, G.J. (1976). Problems of informed consent and confidentiality in genetic counseling. In: Milunsky A., Annas, G.J. (eds). Genetics and the law. New York: Springer, Boston, MA.

[10.] Asamari, A.A. (2015). The provision of Guidance and counseling services in colleges of education in northern Ghana. Retrieved November 20,2018 from https:/ www.ir.uew.edu.gh>bitsream>handle> . 
[11.] Atise, S.A. (2013). The impact of guidance and counseling services on students' academic life, the case of Kusanaba Senior High School in the Bawku West District. University of Education, Winneba. An Unpublished M.Ed. Dissertation.

[12.] Awinsong, M., Omar,D. \& Gidiglo, E.B.(2015). Students' perception of the role of counselors in the choice of a career: A study of Mfantseman municipality in Ghana.RetrievedNovember14,2018from.https://www.researchgate.net/publication

[13.] Bandura,A .(1977). A social learning theory. New Jersey: Prentice-Hall Inc. Englewood cliffs.

[14.] Barki, B.G. \&Mukhopadhyay, B. (1986). Guidance and counseling, a manual. New Delhi: Sterling Publishers.

[15.] Bauman,S., Siegel, J., Falco, L., Szymanski, G., Davis, A., \& Seabolt, K. (2003). Trends in school counseling journals: The first fifty years. Professional School Counselling, 7(2),79-90.

[16.] Beale, A.V. (2004). Questioning whether you can have a contemporary school counseling programme. The Clearing House, 78(2),73-76.

[17.] Bedu- Addo, P.K.A. (2014). Guidance and counseling “Unmasked” (4 ${ }^{\text {th }}$ Ed.). Kumasi: Approacher's Ghana.

[18.] Beesely, D. (2004). Teachers' perceptions of school counselor effectiveness: collaborating for student success. Education,125(2), 259-270.

[19.] Belkin,G.S.(1973). Practical counseling in the schools. Dubugue, IA: WMC. Brown Publisher.

[20.] Bigman, G. \& Campbell, C.(2003). Helping students improve academic and school success behavior. Professional School Counseling, 7(2),91. Retrieved November 28,2018 from EBSCOHOST.

[21.] Brammer, L.M. (1973). Crisis counseling. Retrieved November 12, 2017 from https://books.google.com.gh

[22.] Brammer,L.M. (1973). The helping relationship, process and skills. New Jersey: Prentice Hall.

[23.] Brockopp, G.W. (1973). Crisis intervention: Theory, process and practice. Springfield: Charles C. Thomas.

[24.] Brooks, L. (1974). Interactive effects of sex and status on self-disclosure. Cambridge: Journal of counseling psychology, Careers Research and Advisory Center (CRAC).

[25.] Brown, D. (1999). Improving academic achievement: what school counselors can do. RetrievedNovember17,2018 from https://www.files.eric.ed.gov $>$ fulltext.

[26.] Bryan, J., \& Holcomb-McCoy, C. (2004). School counselors' perceptions of their involvement in school-family-community partnerships. Professional school counseling, 7,162-171.

[27.] Carkuff, R. (1983). The art of helping ( $5^{\text {th }}$ Ed.). Arntherst: Human Resources Press.

[28.] Corey, G. (1986). Transactional Analysis. Retrieved November 28,2018 fromhttps://www.cengage.com>downloads.

[29.] Davis, J.L. \& Mickelson, D.J. (1994). School Counselors: Are you aware of ethical and legal aspects of counseling? School counselor,42,5-13.

[30.] Dinkmeyer, D. (1966). Development counseling in the Elementary school. The Personnel and Guidance Journal, 45(3). Retrieved November,12,2017 from https://onlinelibrary.wiley.com>doi>abs.

[31.] Eremie, M.D. (2015). Teachers' perception of the roles of guidance counselors in secondary schools in Rivers State. Arabian Journal of Business and Management Review. Retrieved November 14,2018 from https://www.omicsonline.org/

[32.] Florida Department of Education (2001). School counseling and guidance framework. Tallahassee, Florida.www.fldoe.org.

[33.] Gatua, M.D., Sindabi, A.M., Chepchieng, M.C. (2015). Impact of guidance and counseling services on students' behavior modification between selected public urban and rural secondary schools in Rift valley Province, Kenya. Journal of Research on Humanities and Social Sciences,5(19). Retrieved November 12, 2017 fromhttps://www.ku.ac.ke>stories>2016.

[34.] Gitonga, F. (1999). Status of guidance and counseling in secondary schools in Thika district. M.A. Unpublished Thesis, Kenyatta University.

[35.] Gyspers, N. C., \& Henderson, P. (2001). Comprehensive guidance and counseling programs: A rich History and a Bright Future. Professional School Counseling, 4(4), 246-257. 
[36.] Harding, A.K., Gray, A. \& Marianne, N. (1993). Confidentiality limits with clients who have HIV: A review of ethical and Legal Guidelines and Professional Policies. Journal of counseling \& Development, 71(3).

[37.] Havinghurst, R. (1980). Lifespan development psychology and education. Educational researcher. 38.

[38.] Herr, E.L. \& Cramer, S.H. (1996). Handbook on career counseling. Retrieved November12,2017 from https://www.unesdoc.unesco.org>images.

[39.] Howe, S. A.(2009). School counseling services and student academic success. Counselor Education. Master's Thesis 54. Retrieved November 17,2018 fromhttp://digitalcommons.brockport.edu/eductheses.

[40.] Ibrahim, F.R., Aloka, J.O.P., Wambiya, P. \& Raburu, A. P. (2014). Perceptions on the role of guidance and counseling programme on Kenya Secondary School Students' career decision making. Retrieved on November, 14,2018 from http://www.researchgate.net>publication.

[41.] Isaac, M.L. \& Stone, C. (1999). Confidentiality with minors: Mental health counselors' attitudes towards breaching or preserving confidentiality. Journal of Mental Health, 23, 342-357.

[42.] Jenkins, P. (2010). Having confidence in therapeutic work with young people: constraints and challenges to confidentiality. British Journal of Guidance \& counseling. 38(3) 263-274.

[43.] Johnson, D.E. (1970). Barriers and hazards in counseling. Boston: Houghton Mufflin.

[44.] Johnson, M.E. (1988). Influences of gender and sex role orientation on help-seeking attitudes. Journal of Psychology: Interdisciplinary and Applied, 122 (3), 237-241.

[45.] Kankam, G., \& Onivehu, O.A. (2000). Principles and practice of guidance and counseling. Accra: K "N" AB Ltd.

[46.] Kartika, A. (2009). The effects of counseling and career development to enhance students'awareness of their personal and study problems. University of Surabaya, Indonesia. Unpublished M.Ed. Dissertation.

[47.] Kituyi,O.W.(2014). Guidance and counseling practice in relation to academic performance. University of Naroibi. Unpublished M.Ed. Thesis.

[48.] Kottler, J.A. \& Brown, R.W. (1996). Introduction to therapeutic counselling. ( $3^{\text {rd }}$. ed.). US: Brooks/Cole Publishing company.

[49.] Kusi, H. (2012). Doing qualitative research, a guide for researchers. Accra: Emmpong Press.

[50.] Lapan, R.T., Gysbers, N.C., \& Ptroski, G.F. (2003). Helping seventh be safe and successful: A statewide study of the impact of comprehensive guidance and counseling programme. Professional School Counselling, 6(13), 186-197.

[51.] Lazovsky, R. (2008). Maintaining confidentiality with minors: Dilemmas of school counselors. Professional school counseling,11, 335-346.doi: 10.5330/PSC n.2010-11.335.

[52.] Leong, F.T. L., \& Zachar, P. (1999). Gender and opinions about mental illness as predictors of attitudes towards seeking professional psychological help. Retrieved November,14,2017 from https:// www.tandfonline. com.

[53.] Leviton, S.K. (1997). Counselor feedback on secondary school guidance programme. Personnel land Guidance Journal 55,242-244.

[54.] Lieberman, A. (2004). Confusion regarding school counselor functions: School leadership impacts role clarity. Education ,12(2),104-117.

[55.] Loan , D.T.B. \& Van, N.T. (2015). Career guidance in secondary schools- A literature review and strategic solutions for Vietnamese rural areas. American International Journal of social science, 4(5). Retrieved November,12,2017 from https://www.aijssnet.com>journals>vol 4-No.

[56.] Mackenzie, C.S., Gekoski, W.L. \& Knox, V.J. (2006). Age, gender, and the underutilization of mental health services: the influence of help-seeking attitudes. Journal of Aging Mental Health,10 (6): 57482.

[57.] Makinde, O. (1984). Fundamentals of guidance and counseling. London: MacMillan.

[58.] Makinde, O. (1987). Fundamentals of guidance and counseling. London: MacMillan.

[59.] Mason, C.P. \& Duba, J.D. (2009). Using reality therapy in schools: Its potential impact on the effectiveness of the ASCA national model. International Journal of reality therapy, 29 (1), 5-12. 
[60.] Mbabu, J.W. (2005). The role of guidance and counseling in prevention of abortion amongst Kenyan public university students: A case study of Kikuyu campus. The University of Nairobi. Unpublished M.Ed. Dissertation.

[61.] Mckenzie, K., Murray, K.R., Murray, A.L. \& Richelieu, M. (2015). The effectiveness of university counseling for students with academic issues. Journal of counseling and Psychotherapy Research, 15(4).

[62.] Ministry of Education (2017). Career information. Singapore. Retrieved November,14,2017 fromhttps://www.moe.gov.sg/career>teach.

[63.] Moyer, M. \& Sullivan, J. (2008). Student risk-taking behaviors: When do school counselors break confidentiality? Professional School Counselling, 11,236-245.doi:10.53330/PSC.n.2010-11.236.

[64.] Moyer, M. \& Sullivan, J.R. (2008). Student Risk taking behaviors: When do school counselors break confidentiality. Retrieved November, 12, 2017 from http:// journals.sagepub.com>doi>abs.

[65.] Myrick, R.D. (1987). Developmental guidance and counseling: A practical approach. Retrieved November 12,2018 from https://eric.ed.gov/? id=ED3464.

[66.] Myrick, R.D. (2003). Accountability: Counselors Count. Professional School Counseling, (3), 174-180.

[67.] Nam, K.S., Jung, H. C., Lee, M.K., Hee, L.J. (2010). A meta- analysis of gender differences in attitudes towards seeking professional psychological help. Journal of American College of Health, 59 (2) 110-6.

[68.] Ndirangu, P.N. (2007). The influence of guidance and counseling programme on academic performance of selected performance of selected public secondary school students: A case of Bahati division, Nakuru district. Egerton university. Unpublished M.Ed. Dissertation.

[69.] Nelson, J.R.,Covin, G., \& Smith, D. (1996). The effects of setting clear limits on the social behavior of students in the commons areas of schools. Journal for At-Risk Issues, 3, 10-19.

[70.] Ng'eno, G.K. \& Magut, A. (2014). Students' perception of the impact of guidance and counseling programmes on the satisfaction of vocational needs in selected Kenyan secondary schools. Journal of Education and Practice, 5(36). RetrievedNovember,12,2018 from https://www.iiste.org $>$ article $>$ viewfile.

[71.] Nyan,C.F. (2014). Students' and teachers perception of guidance and counseling services in Eastern Uganda: Case study of secondary schools in Pallisa District. Makerere University. Retrieved November,18,2018 from https://www.makir.mak.ac.ug>handle.

[72.] Odhiambo, O.D. (2012). Influence of guidance and counseling on academic performance of students in selected public secondary schools in Molo Sub County, Nakuru County, Kenya. International journal of Science and Research. Retrieved November,12,2017from https://www.ijsr.net.

[73.] Omolewa, M. (2000). The state of Adult and Continuing education in Africa. Retrieved November 12,2017 from https:// www.researchgate.net>publication.

[74.] Organization for Economic co-operation and development (OECD) (2004). Career guidance and public policy. Retrieved November 12,2017 from https://www.oecd.org>innovation- education.

[75.] Parham, W.O. \& Tinsley, H.E. (1980). What are friends for? Students expectations in friendship encounters. Journal of counseling psychology.

[76.] Patterson, C.H. (1973). Theories of counseling and psychotherapy (2 ${ }^{\text {nd }}$ ed.). New York: Harper \& Row.

[77.] Pietrofesa, J.J. (1973). The school counselor in sex education. Personnel and guidance journal, 54(15)11-18.

[78.] Pietrofesa, J.J. (1976). The school counselor and sex education. The Personnel and Guidance Journal, 54(7). Retrieved November,12,2017 from https://onlinelibrary.wiley.com

[79.] Pietrofesa, J.J., Hoffman, L.R., \& Splete, L. (1984). Types of counseling. Retrieved November,14,2017 from https:// books.google.com.gh.

[80.] Poal, P. (1990). Introduction to the theory and practice of crisis intervention. RetrievedNovember, 12,2017 from https://www.raco.cat>article>download.

[81.] Purkey, W.W., \& Schmidt, J.J. (1996). Invitational counseling. Pacific Grove, CA: Brooks/Cole.

[82.] Racho, I., Aloka, J.O., Wambiya, L. \& Raburu, P. (2014). Perceptions on the role of guidance and counselling programme in Kenyan secondary school students' career decision making. Journal of Educational and Social Research Vol.4 No.6. 
[83.] Reiner, S.M., Colbort, R.D., Perusse, R. (2009). Teachers perceptions of the professional school counsellor role: A national study. Professional School Counseling,12(5),324-332.

[84.] Renuka, D.M.R., Devaki, P.R., Madhanika, M., \& Saikumar, P. (2013). The effects of counseling on the academic performance of college students. Journal of clinical \&Diagnostic Research, 7(6): 10861088.

[85.] Rogers, C.R. (1967). Client-centered therapy. Boston: Houghton Mifflin.

[86.] Schmidt, J.J. (2003). Counselling in schools: Essential services and comprehensive programmes $\left(4^{\text {th }}\right.$ ed.). Boston: Houghton Mifflin.

[87.] Shannon, T.B., Morgan, R., Kiper, E. and Shillingford, M.A. (2008). School counsellors' constructions of student confidentiality. Journal of school counseling, 11(12).

[88.] Shaterloo, A \& Mohammadyari, G. (2011). Students counseling and academic achievement. Retrieved November 17,2018 from https://www.researchgate.net/>publication.

[89.] Shertzer, B. \& Stone, S. C. (1980). Fundamentals of counseling. ( ${ }^{\text {rd }}$ ed.). Boston: Houghton Mifflin Company.

[90.] Sink, C.A. (2008). Elementary school counselors and teachers: Collaborators for higher student achievement. Elementary school Journal, 108(5), 445-458.

[91.] Standing Conference of the Association for Guidance in Education settings, U.K. (1992). Career guidance in secondary schools. Retrieved November 12,2017 from https://www.rroij.com>openaccess>career-guidance.

[92.] Stone, C.B. \& Dahir, C. (2003). A measure of the impact school counsellors have on students' achievement. Retrieved November 18, 2018 from https://www.researchgate.net>publication.

[93.] Sultana, R.G. \& Watts, A.G. (2005). Career guidance in public employment services across Europe. International Journal for Educational and Vocational Guidance, (2006) 6:29-46.

[94.] Tinsley, H.E., De St Aubin, T.M., \& Brown, M.T. (1982). College students' help-seeking preferences. Journal of Counseling Psychology, 29 (5), 523-533.

[95.] Trusty, J., Mellin, E.A., \& Herbert, J.T. (2008). Closing achievement gaps: Roles and tasks of elementary school counselors. Elementary School Journal, 108 (5), 407-421.

[96.] U.S. Department of Education (2002). High quality school counseling services. Connecticut.

[97.] Van Hoose, H.W. \& Worth, M.R. (1982). Human development. Retrieved November,12,2018from https: //books.google.com>books>about.

[98.] Watts, A. G., Fretwell, D.H. (2004) Public policies for career development: case studies and emerging issues for career information and guidance systems in developing and transition economies. Retrieved November 12,2017 from https://documentsworldbadnk.org/curated/en/546071468763-805157/.

[99.] White, S.W., \& Kelly, F.D. (1976). The school counselor's role in school dropout prevention. Journal of counseling and development, 88(2). Retrieved November,12,2017 from https://www.researchgate.net> publication.

[100.] Willys, W. (2017). Factors that influence students' perception of Counsellors roles and functions in institutions of higher learning: A case of universities and colleges in Mount Kenya East Region. Unpublished M.A. dissertation. 